NBER WORKING PAPER SERIES

\title{
"TO ESTABLISH A MORE EFFECTIVE SUPERVISION OF BANKING": HOW THE BIRTH OF THE FED ALTERED BANK SUPERVISION
}

\author{
Eugene N. White \\ Working Paper 16825 \\ http://www.nber.org/papers/w16825 \\ NATIONAL BUREAU OF ECONOMIC RESEARCH \\ 1050 Massachusetts Avenue \\ Cambridge, MA 02138 \\ February 2011
}

For their comments and suggestions, I would especially like to thank Michael D. Bordo and William Roberds and the participants in seminars at the Federal Reserve Board, Harvard University, Rutgers University, Yale University, and the Return to Jekyll Island Conference. The views expressed herein are those of the author and do not necessarily reflect the views of the National Bureau of Economic Research.

NBER working papers are circulated for discussion and comment purposes. They have not been peerreviewed or been subject to the review by the NBER Board of Directors that accompanies official NBER publications.

(C) 2011 by Eugene N. White. All rights reserved. Short sections of text, not to exceed two paragraphs, may be quoted without explicit permission provided that full credit, including $\odot$ notice, is given to the source. 
"To Establish a More Effective Supervision of Banking": How the Birth of the Fed Altered Bank Supervision

Eugene N. White

NBER Working Paper No. 16825

February 2011

JEL No. E58,G21,G28,N11,N12,N2

\begin{abstract}
Although bank supervision under the National Banking System exercised a light hand and panics were frequent, depositor losses were minimal. Double liability induced shareholders to carefully monitor bank managers and voluntarily liquidate banks early if they appeared to be in trouble. Inducing more disclosure, marking assets to market, and ensuring prompt closure of insolvent national banks, the Comptroller of the Currency reinforced market discipline. The arrival of the Federal Reserve weakened this regime. Monetary policy decisions conflicted with the goal of financial stability and created moral hazard. The appearance of the Fed as an additional supervisor led to more "competition in laxity" among regulators and "regulatory arbitrage" by banks. When the Great Depression hit, policy-induced deflation and asset price volatility were misdiagnosed as failures of competition and market valuation. In response, the New Deal shifted to a regime of discretion-based supervision with forbearance.
\end{abstract}

Eugene N. White

Department of Economics

Rutgers University

75 Hamilton Street

New Brunswick, NJ 08901-1248

and NBER

white@economics.rutgers.edu 
"An Act to provide for the establishment of Federal reserve banks, to furnish an elastic currency, to afford means of rediscounting commercial paper, to establish a more effective supervision of banking in the United States, and for other purposes."-the title of the Federal Reserve Act of 1913 [emphasis added]

While the formation and development of the Federal Reserve has been intensively studied, histories of the Fed, from Milton Friedman and Anna J. Schwartz's Monetary History (1963) to Allan H. Meltzer's History of the Federal Reserve (20032009), have focused almost exclusively on monetary policy. ${ }^{1}$ The quiet work of bank supervision has seemed somewhat pedestrian compared to the high profile determination of interest rates, monetary aggregates and exchange rates. Yet, the founders of the Fed regarded bank supervision as a key element in their new policy regime, placing it in the title of the Federal Reserve Act. Unfortunately, in spite of this headlining, the effective approach to bank supervision that had developed under the National Banking System was slowly undermined in the Fed's first decade and a half.

Although the National Banking System had frequent banking panics that increased the severity of recessions, its regulation and supervision successfully limited losses to depositors. Supervision before 1913 had a relatively light hand and may be characterized as a regime that aimed at reinforcing market discipline with prompt closure of insolvent institutions. Its panics were primarily driven by liquidity problems rather than solvency issues, even if a few bank failures inaugurated a panic. The underlying causes of these frequent crises were the prohibition on branch banking, which created a fragmented system of undiversified unit banks, and the absence of a central bank.

The situation in which reformers found themselves after the Crisis of 2008 would not have been unfamiliar to the fathers of the Federal Reserve System. After a half century, the banking regime created during the Civil War was outdated. Ignited by the collapse of fast-growing new institutions outside the federal "safety net," the Panic of 1907 led to a demand for an overhaul of the regulatory system. In response, the Federal

\footnotetext{
${ }^{1}$ Even contemporary authorities remained relatively mute on the subject. Charles Dunbar's classic banking text, The Theory and History of Banking $\left(1^{\text {st }}\right.$ ed. $1891,5^{\text {th }}$ ed. 1929), makes on the briefest mention of examination and supervision: "The Board exercises many supervisory functions over the reserve banks which are similar to those which have long been exercised by the Comptroller of the Currency over national banks. Examination of reserve banks is under its direction.” Dunbar (1929), p. 311.
} 
Reserve Act created a lender of last resort and sought to subject state-chartered banks and trust companies that had operated with weaker regulations to federal rules.

When the Fed opened for operation in 1914, a conflict immediately arose with the Comptroller of the Currency over which agency would control federal supervision. Competition between these agencies slowly weakened oversight of banking. In addition, the opening of the discount window provided a new option for troubled member banks. Previously, when a bank saw declining profitability and the possibility of failure, its directors might close the bank in advance of insolvency, fearful of the penalty of double liability that would fall upon them and the other shareholders, should the bank fail. These voluntary liquidations kept the number of actual insolvencies relatively low. Under the new regime, a troubled member bank now could obtain loans from the discount window, enabling it to continue operation in the hope of recovery.

Although the new Federal Reserve regime of bank supervision weakened the effectiveness of the pre-1913 system and raised the costs of bank failures, it left most of its principal elements in place. This old regime was only toppled when the Great Depression led to a loss of faith in markets. Under the New Deal, supervision designed to reinforce market discipline was replaced by discretionary supervision with forbearance, setting the stage for the crises of the late twentieth century. ${ }^{2}$

\section{The Problems of the National Banking System, 1864-1913}

\section{A. Origins}

The Panic of 1907 and subsequent recession of 1907-1908 highlighted the need to redesign the National Banking System. This ageing regulatory regime was the product of an earlier effort to tackle the key issues of how to ensure financial stability. Following the expiration of the Second Bank of the United States' charter in 1836, the federal government abandoned any role in the regulation of the banking system. The states then experimented with a variety of regimes, but the predominant one was "free banking." This type of banking system had two key characteristics: free entry or very low barriers to entry and the issue of banknotes by each individual bank that were guaranteed by the

\footnotetext{
${ }^{2}$ For a discussion of the various U.S. supervisory regimes and regulatory issues, see Mishkin (2001), White (2009), and Alesina and Stella (2010).
} 
purchase of an equivalent amount of state bonds valued at par. ${ }^{3}$ After some initial difficulties, these state "free banking" systems expanded, providing increased intermediation and a relatively safe currency. However, the unanticipated shock of Civil War undermined many state systems. As the values of state bonds fell, the backing or insurance behind banknotes declined, producing a wave of failures. ${ }^{4}$ In 1861, there were 1,601 banks, dropping to 1,492 a year later. ${ }^{5}$

Congress responded to this crisis, and the desire to build a deeper market for federal bonds, by creating the National Banking System. Patterned on the states' antebellum systems, the National Currency Act of 1863 and the National Bank Act of 1864 established a federal "free banking" system. While setting high standards for reserve requirements, minimum capital, and lending, the objective was to create a nationwide federal system generating a large number of new "national" banks and absorbing the state banks. ${ }^{6}$ The banknotes issued by national banks were given a much better backing than state banknotes had secured---U.S. government bonds---which ultimately provided a uniform, perfectly safe currency for the public. The Act of 1864 also created the Office of the Comptroller of the Currency (OCC) to examine the national banks and ensure that they complied with the regulations. The agency's name emphasized the initial primacy of protecting the security of national banknotes.

In terms of the key design issues for a supervisory regime, the National Banking System was remarkably simple. There was no central bank, and high-powered money was largely determined by the balance of payments under the Gold Standard. ${ }^{7}$ Hence there was no potential conflict price stability and financial stability because of the monetary policy conducted by the central bank. The absence of a central bank also made bank supervision completely independent. If Congress had succeeded in winding down the state banking systems, with their separate state regulatory agencies, there would have been only one nationwide regulator of the banking system, the OCC. Although the OCC was formally a bureau of the Treasury, it was granted a considerable degree of

\footnotetext{
${ }^{3}$ See Rockoff (1974), Rockoff (1975), Rolnick and Weber (1983)

${ }^{4}$ Economoupoulos (1988), Rolnick and Weber (1984).

${ }^{5}$ Carter (2006), Series Cj203.

${ }^{6}$ For details, see James (1976) and White (1983).

${ }^{7}$ The United States went off the bimetallic standard in 1861. Resumption took place in 1879, with the nation moving to a de facto gold standard.
} 
independence. The head of the agency, the Comptroller, was appointed by the President on the nomination of the Secretary of the Treasury, with the advice and consent of the Senate for a term of five years, freeing the Comptroller for the immediate pressures of the electoral cycle. Although most pre-1914 Comptrollers did not complete a full term, some were renewed. ${ }^{8}$ The Comptroller was given a salary of $\$ 5,000$, but he was required to post a substantial bond of $\$ 100,000$ for the faithful discharge of his duties. He was also given a Deputy Comptroller with half the salary and half the bond and the right to hire the necessary clerks and examiners. The agency reported regularly to Congress providing highly annual detailed reports. Concerned about the safety of the bank-issued currency, the examiners valued assets according to the market and were charged with prompt closure in the event that they discovered a bank to be insolvent.

Yet, state banks did not all join the National Banking System, as they recoiled at the prospect of meeting the new tougher national bank regulations. In 1865, Congress responded to this resistance by imposing a 10 percent tax on state bank notes, a vital means for funding their loans. Although state banks did not completely disappear, national banks became the dominant financial institutions. This victory is seen in Figure 1 , which reports the number of banking institutions by charter type. By 1870, there were 1,612 national banks and a mere 325 state banks, with national banks holding 88 percent of all bank assets. ${ }^{9} \quad$ For the next two decades, national banks maintained their preeminence across the country. Although a few states permitted some limited type of branching, all national banks were unit or single-office banks. Based on the National Banking Act's requirement that a national bank's "usual business shall be transacted at an office or banking house located in the place specified in its organization certificate," the second Comptroller of the Currency ruled in 1866 that branches were forbidden. ${ }^{10}$

\footnotetext{
${ }^{8}$ The longest serving pre-1914 Comptroller was John Jay Knox, April 25, 1872-April 30, 1884.

${ }^{9}$ Carter (2006), Series Cj203 and Cj204.

${ }^{10}$ In an era where communications were slow, this decision may have made sense from an examiner's point of view, as it would be difficult to examine a bank and its branches simultaneously.
} 
Figure 1

The Number of Bank by Charter Type

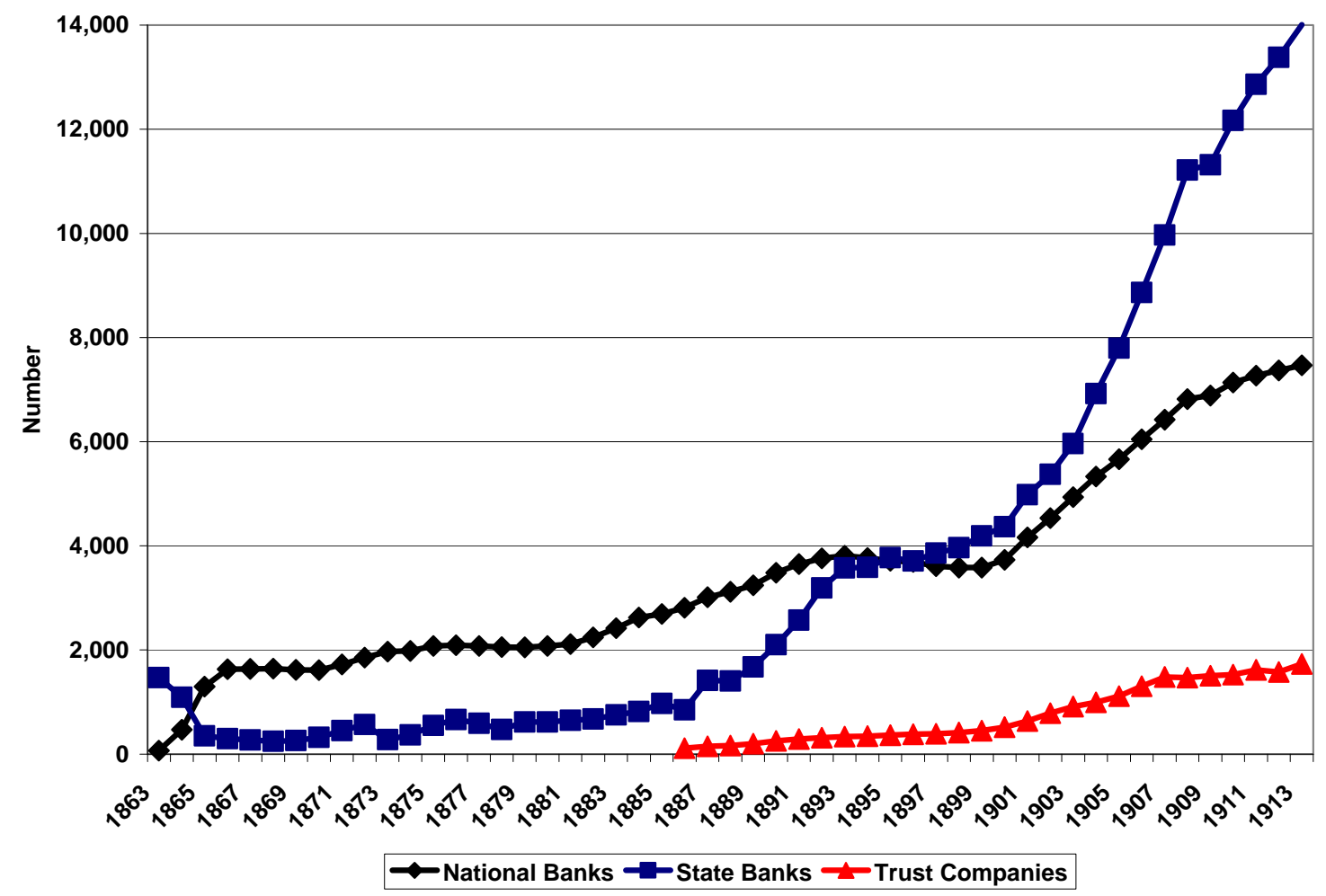

Source: Carter (2006), Series Cj203, Cj212, Cj149, Bell (1928)

\section{B. The Re-Emergence of State Banks}

The strict regulatory regime imposed on national banks created incentives for innovations that would slowly undermine National Banking System. Given that states retained their authority to charter financial institutions, they played a crucial role in these developments, which would have profound consequences for the stability of the financial system. Over the course of the next several decades, individual states, seeking to expand the number of financial institutions within their borders revised their bank legislation. They engaged in "competition in laxity" by lowering their minimum capital, reserve and lending requirements, which resulted in a "regulatory arbitrage" with institutions searching for the least onerous regulations. ${ }^{11}$ National banks found two new competitors,

\footnotetext{
${ }^{11}$ The success of the growing state banking systems ultimately forced Congress to reduce the lowest of the tiered minimum capital requirements. In 1864 , this requirement set $\$ 50,000$ as the minimum capital for towns with a population under 6,000. The Gold Standard Act of 1900 set a new lower bound of $\$ 25,000$ for the minimum capital required for banks starting up in towns with a population of under 3,000. White (1983).
} 
typically one type on the agricultural frontier-state banks---and the other in the growing urban centers---trust companies.

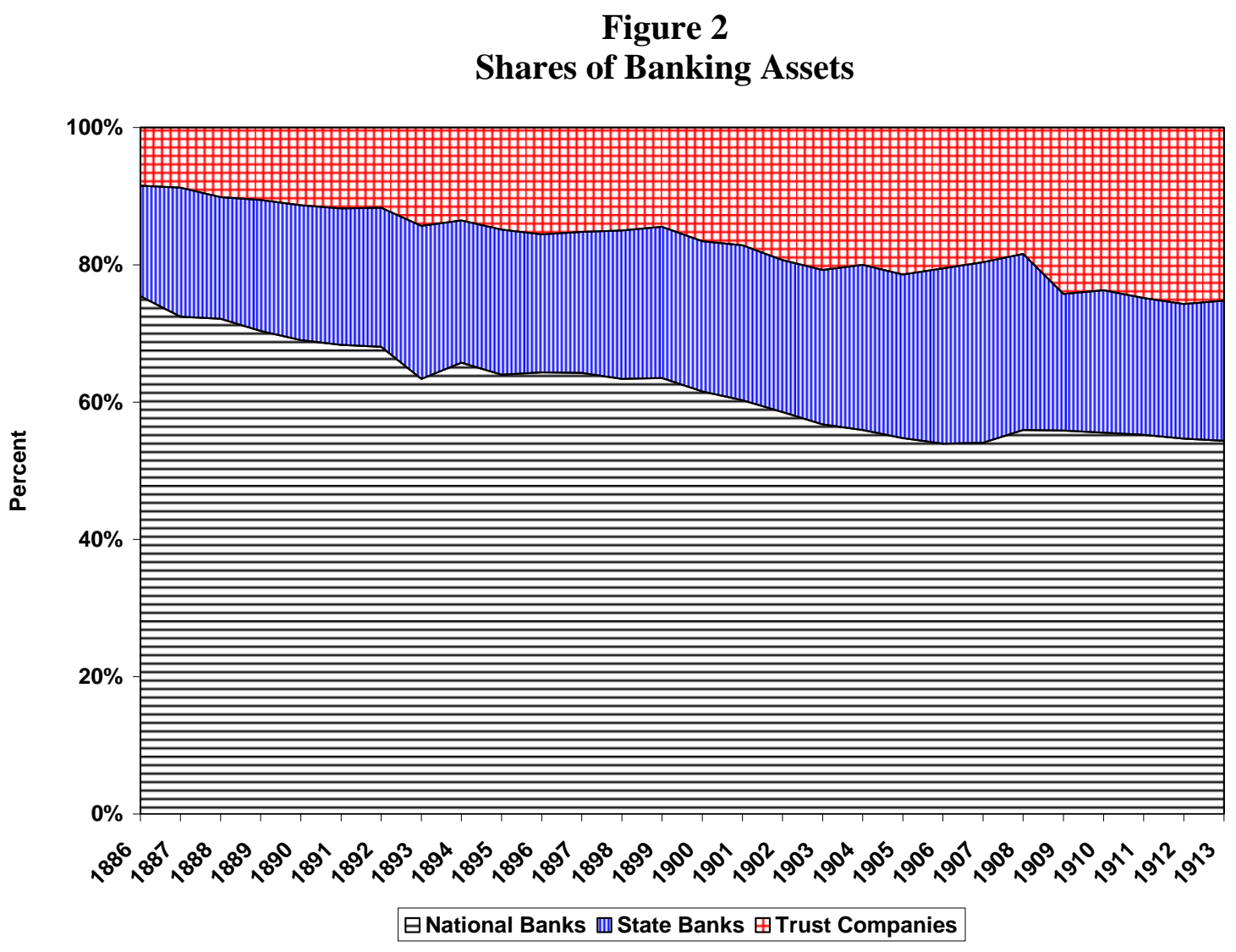

Source: Carter (2006), Series Cj204, Cj213, and Cj150 and White (1983), pp. 12-13.

State-chartered banking systems began to revive in the third quarter of the nineteenth century when states revised their banking codes and set regulations that were considerably weaker than those governing national banks. Most importantly, the states substantially lowered the minimum capital needed to open a bank. ${ }^{12}$ Combined with the general prohibition of branch banking and steady economic growth, these regulations encouraged a rapid increase in the number of very small banks throughout the country, particularly the Midwest and West. State banks eventually outnumbered the national banks by late 1890s, and then experienced an explosive growth in the early twentieth century, garnering an increased share of assets, as seen in Figures 1 and 2. They were able to expand because they developed deposit banking more quickly than national banks. Figure 3 shows that before the Civil War banknotes and deposits played roughly

${ }^{12}$ For details of this competition in laxity, see White (1983), Chapter 1. 
an equal role in funding state bank lending, with capital representing the other major share. By the 1850s deposit banking was gradually moving ahead of the use banknotes. The national banks seem to follow these trends; but the state banks, forced by the 1865 tax to abandon note issue, focused on deposit creation, reaching a share of deposits to liabilities that national banks only matched in 1900. The constraints on national banknote issue, notably the declining number of outstanding U.S. government bonds, kept banknotes' share of funding very modest. ${ }^{13}$ The result was the national bank regulations that "insured" banknotes protected a smaller and smaller share of bank customers, as "uninsured" deposits soared, opening the potential for greater losses in the event of a failure.

Figure 3

Sources of Funding for State Banks and National Banks

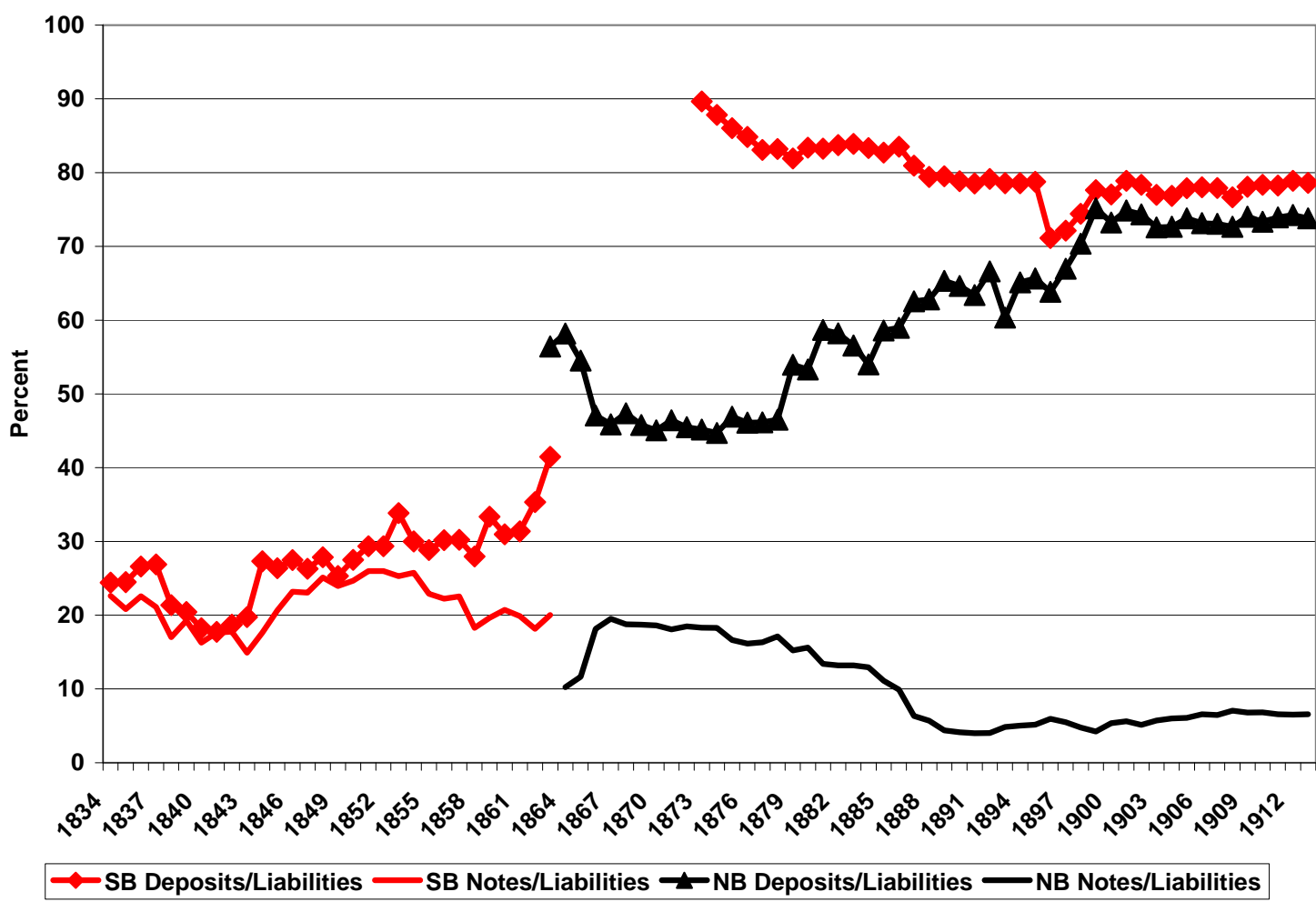

Source: Carter (2006), Series Cj159, Cj160, Cj155, Cj170, Cj156, Cj204, Cj227, Cj209, Cj209, Cj210, Cj235.

\footnotetext{
${ }^{13}$ There is a large literature on the "conundrum" of low national banknote issue. For example, see James (1976), Cagan and Schwartz (1991), and Champ, Wallace, and Weber (1992).
} 
The result of the rapid growth of single office banks was the emergence of two serious weaknesses in the American banking system that did not appear in Canadian or European banking systems where branching was permitted and entry often limited by high initial minimum capital requirements: (1) Many small American banks' loan and deposit bases were relatively undiversified so they were more vulnerable to shocks and prone to failure and (2) An elaborate correspondent banking system was necessary to link these banks with national money markets and facilitate the clearing of checks. The correspondent system was further encouraged by high federal and state reserve requirements that permitted banks to hold their part of their reserves outside of their own vault and in accounts at major city banks where they earned interest. These large pools of liquid funds, concentrated primarily in New York, were invested by city banks in call loans to the stock market. The financial system was thus integrated but potentially fragile. Panicked country banks could withdrawal their deposited funds from money centers, stressing city banks and financial markets. This fragmentation of the banking system and the correspondent banking system thus played key roles in nineteenth century panics, including 1907.

\section{The Rise of the Trust Companies}

The second class of institutions that challenged the National Banking System was the trust companies, permitted to combine traditional banking with trust operations, which were banned to national banks. These institutions opened under state charters with regulations that were often weaker than the regulations governing state banks. ${ }^{14}$ They prospered in the financial centers where they became tough competitors of national banks. ${ }^{15}$ Trust companies grew at an astonishing rate in New York State. In 1897, national banks had \$915 million in assets, state banks \$297 million, and trust companies $\$ 396$ million in New York. ${ }^{16}$ But only a decade later, in 1907, while national banks had grown to $\$ 1.8$ billion and state banks to $\$ 541$ million, trust companies had expanded to $\$ 1.4$ billion in assets. The effects of the new entrants on the banking system are visible in Figures 1 and 3. The number of trust companies rose quickly in the last decade of the

\footnotetext{
${ }^{14}$ Barnett (1911)

${ }^{15}$ Neal (1971).

${ }^{16}$ See Barnett (1911) p. 235, for more details.
} 
nineteenth and the first decade of the twentieth centuries. As they were larger urban institutions, they did not challenge national and state banks in sheer numbers, but they did garnered a larger share of all bank assets. While their share was just over 20 percent nationally, they were more important in financial centers. Furthermore, they operated outside the federal regulatory system, sometimes with only modest state oversight.

The fragmented system of unit banks, tied together by correspondent balances, could turn a banking panic by the public into a bankers' panic. In spite of this fragility, there was no central bank. Central banks were created by most developed countries by the end of the nineteenth century; but the political economy of the U.S. prevented the establishment of one. The problems created by the absence of a central bank were highlighted by the discussion about the "inelasticity" of national banknotes or what today would be termed the inability to expand high-powered money/currency to the financial system in response to crises. National banknotes were tied to the outstanding stock of government bonds, and they did not increase when there was a flight to cash during seasonal stringencies, common in this period, and financial panics.

The private market provided only a partial solution to the absence of a central bank by its temporary issue of clearing house loan certificates in crises. These instruments, backed by the assets of individual banks, gave some additional liquidity, especially to the clearing operations between banks. But to participate, banks had to be members of the clearing houses. In these institutions, banks had to trust one another completely because of the large balances that they built up against one another before settlement. To alleviate concern, they monitored each other more closely and frequently than the official federal and state regulators. Thus, they had particularly good information on the solvency of their members. During panics, the creation of high denomination clearing house loan certificates enabled banks to replace coin and banknotes in their clearing house exchanges, enabling their to pay out more cash to their nervous depositors. Their success eventually led to the issuance of small denomination notes that circulated with the public briefly in times of crisis. ${ }^{17}$

Clearing house loan certificates helped to alleviate earlier panics, but the Panic of 1907 reflected the most recent evolution of the financial system: the emergence of the

${ }^{17}$ Cannon (1910), Friedman and Schwartz (1963). 
trust companies as a "shadow" banking system, competing with but not fully accepted by their more heavily regulated rivals, the banks. As they did not conform to the same regulations as the banks, they could only corresponding members not full of the clearing houses, as the banks were dead set against allowing these rivals to gain the added protection of the clearing house. The Panic of 1907 exploded when the Knickerbocker Trust Company, a major New York financial institution approached the New York Clearing House for assistance. When it was denied, the news prompted a run on all trust companies that eventually spread to the banks. Neither the intervention by J.P. Morgan or the U.S. Treasury proved sufficient to halt this panic, which was only contained by the declaration of a suspension of payments by banks. ${ }^{18}$

\section{Panics}

The obvious fear of reformers in the latter years of the National Banking era was the frequency and severity of banking panics, which occurred at both regional and national levels. Two studies commissioned by the National Monetary Commission, established after the Panic of 1907, examined these crises. O.M.W. Sprague's volume focused on the crises of 1890, 1893 and 1907 but Edwin W. Kemmerer's close reading of the Commercial and Financial Chronicle uncovered eight major and twenty-one minor panics. ${ }^{19}$ Subsequent scholarship has identified five major banking panics between 1864 and the founding of the Fed: 1873, 1884, 1890, 1893 and $1907 .{ }^{20}$ Some of these panics did not degenerate into a full-blown scramble for liquidity, and 1884 and 1890 are sometimes classified as “incipient panics” or moments of "financial distress."

It is widely agreed that these panics had severe consequences for the economy. Pointing to six recessions that hit the U.S. between 1895 and 1912, Allan H. Meltzer concluded that "financial panics, interest rates temporarily at an annual rate of 100 percent or more, financial failures, and bankruptcies were much too frequent." ${ }^{\text {21 } \mathrm{He}}$ emphasized that other countries did not suffer the financial trauma that afflicted the U.S. economy because they had lenders of last resort. Compared to the post-World War II era,

\footnotetext{
${ }^{18}$ Friedman and Schwartz (1963) and Moen and Tallman (1992)

${ }^{19}$ Sprague (1910), Kemmerer (1910).

${ }^{20}$ See Jalil (2009) for a discussion of the differences between the standard sources on the classification of banking panics.

${ }^{21}$ Meltzer (2003), p.9
} 
Christina Romer determined that the pre-Fed era had greater volatility in GNP, industrial production, commodity output, and the unemployment rate. ${ }^{22}$ While the length of recessions was about the same, expansions were considerably longer in the post-World War II period. In general, she found that the frequency and severity recessions were greater before the founding of the Fed. For the years, 1890-1908, Jeffrey Miron reported that panic years had substantially lower real GNP growth than non-panic years and that the elimination of major panics after the founding of the Fed shortened the length of recessions from 17.5 to 14.25 months. ${ }^{23}$ Most recently, Andrew J. Jalil confirmed that panics independently and significantly diminished the growth of output and contributed to deflation. More importantly, recessions with major banking panics were more severe and longer than recessions without panics. ${ }^{24}$

While most scholars would agree that the severity of the 2007-2009 recession was amplified by the Panic of 2008, confirming the pre-1914 pattern, the pre-Fed panics were different. In contrast to the most recent financial collapses, including the banking/savings and loan disaster of the 1980s and the Crisis of 2008, the panics of the National Banking Era were primarily liquidity events rather than solvency events. The scramble for liquidity contributed to the severity of economic downturns, but the panics were not driven by widespread bank insolvencies nor did they create insolvencies that ultimately led to substantial losses to shareholders, depositors and other stakeholders. As liquidity events, the banking industry was subject to massive withdrawals of deposited funds by the public and corresponding banks often leading to a suspension of payments. However, unlike contemporary events, the solvency of the entire banking industry or even a significant fraction was not ultimately in question. In this pre-1914 world, bank regulation and supervision played a crucial role in setting the incentives that limited solvency problems.

\footnotetext{
${ }^{22}$ Romer (1990) compares the years 1886-1916 with 1948-1997, and 27.

${ }^{23}$ Miron (1986) Additionally, for the National Banking era, Grossman (1993) found that a "small bank failure" shock could lead to a 2 percent decline in real GNP while a large bank failure shock could produce a 20 percent decline in GNP.

${ }^{24}$ For the years 1825-1914, the average decline in output for recessions with panics was 7.9 percent, with the average time from peak-to-trough 1.4 years and trough-to-pre-downturn peak 1.7 years, contrasting 4.8 percent, 1.2 years and 1 year for recessions without panics. If only the post-Civil War era is considered the severity and length of recessions with panics is even greater. Jalil (2009), p. 34.
} 


\section{Supervision, 1864-1913}

\section{A. Disclosure}

Of the three basic components of bank supervision---disclosure, examination, and disciplinary action---disclosure was emphasized under the National Banking System. The emphasis on disclosure reflected the belief that market discipline was the best means to ensure the soundness of banks. Because there was detailed proprietary information that could not be revealed to the public, examinations also played a key role in ensuring bank solvency; but, apart from fines for late disclosure of information, the only disciplinary actions a Comptroller could take were the revocation of a bank's charter and the declaration of a suspension with appointment of receivers to liquidate the bank.

The OCC was established to ensure compliance with the new federal regulations. $^{25}$ Initially, national banks were required to provide a detailed quarterly report and a very limited monthly statement. The fixed dates and absence of auditing permitted banks to engage in "window dressing." In 1869, Congress responded to Comptrollers complaints and instituted "call” reports of condition to improve disclosure. National banks were required to provide the Comptroller with five call reports per year with information on their balance sheets; and three of these were set on dates randomly chosen by the Comptroller to limit opportunities for manipulation of banks' books. Every day’s delay in delivery of the call report was subject to $\$ 100$ fine. ${ }^{26}$ These reports appear to have provided significant information, as they were valued by the financial industry. Banks in Reserve Cities requested the Comptroller to publish more frequent information from the call reports so that they could better follow the changing condition of their corresponding banks in the countryside. ${ }^{27}$

\footnotetext{
${ }^{25}$ Regular examinations first appeared in the United States before the Civil War when six states, New York, Vermont, Indiana, Michigan, Ohio and Iowa. Robertson, (1968), pp. 25-6.

${ }^{26}$ Banks were required to report the payment of a dividend within ten days or face a similar penalty Robertson, (1968), pp. 79-81.

${ }^{27}$ In the 1889 Annual Report, the Comptroller asked for an additional appropriation $\$ 10,000$ to fulfill to a request from the American Bankers Association to publish not only call report data for each national bank on the date nearest the first of October but also for the date nearest the first of April. U.S. Comptroller of the Currency (1889), pp.53-54.
} 


\section{B. Examination and Discipline}

While providing information on the general condition of a bank, the call reports were aggregate by nature, and examination was thus a vital component of supervision for detecting fraud and ensuring compliance with regulations by delving into details of bank operations that would be deemed proprietary and inappropriate for public disclosure. The initial purpose behind the examinations was to ensure that banks would be able to redeem their banknotes upon presentation. Examinations were conducted from the "bottom up" where examiners scrutinized the cash, assets and accounts of the bank to ensure that they complied with the letter of the law. ${ }^{28}$ Although Comptrollers sent examiners instructions for examination, they emphasized that there could be no "cast-iron rules covering minute details. $^{29}$

The Comptroller of the Currency was charged with performing a minimum of two examinations per year for all national banks. These examinations were to be unannounced so the bank officials had no opportunity to hide any problems. Examiners were appointed by the Comptroller with the approval of the Secretary of the Treasury. Their compensation was set by statute, as were the assessments levied on banks to fund their payment. Out of these fees, examiners had to pay for expenses and their assistants. Beyond these very basic tenets, no limits were set on the number of examiners that could be appointed; and there were no fixed terms of office, oath of office, bond, or geographical districts, leaving the Comptroller with considerable discretion for deployment of his examiners. ${ }^{30}$ Yet, the Comptroller's ability to increase disclosure by printing more frequent call reports or managing examiners by expanding his staff were limited by fact that his office in Washington D.C. was funded by Congressional appropriation and increases were rarely forthcoming.

National bank examiners were paid a fee for examining a bank, based on the bank's capital. Before the 1875 Amendment to the National Bank Act, an examiner was paid $\$ 5$ for each day of examination and $\$ 2$ for every 25 miles he traveled by the

\footnotetext{
${ }^{28}$ Officers and directors must be "complying with the requirements of the law and whether they are in any way violating any of its provisions.” U.S. Comptroller of the Currency, (1881), p. 35-6.

${ }^{29}$ U.S. Comptroller of the Currency, (1891), p. 26.

${ }^{30}$ U.S. Comptroller of the Currency, (1889), p. 54.
} 
examined bank. ${ }^{31}$ As large city banks were bigger and more complex, compensation for examiners of banks in reserve cities was determined by the Secretary of the Treasury upon recommendation of the Comptroller. A schedule of assessments for banks was set to fund these fees. For banks outside of the established reserve cities, the examination fee ranged from $\$ 20$ for a bank with capital under $\$ 100,000$ to $\$ 75$ for a bank with a capital over $\$ 600,000$.

Although examinations were supposed to be unannounced, the surprise was often compromised by the predictability of an examiner's travel plans given his efforts to minimize cost, enabling banks to prepare for a visit if forewarned. Comptrollers regularly complained about the incentive effects of these legislated fees. In Hearings before the House Committee on Banking and Currency, Representative Joseph W. Babcock reported that cashiers in a chain bank that had been visited by an examiner would telegraph to the other member banks, "the examiner here to-day; lookout, he is coming. ${ }^{32}$ In the 1901, Annual Report, Comptroller William Ridgely recommended the payment of fixed salaries to examiners instead of fees. ${ }^{33}$ Ridgely reiterated his complaint in his report of $1906 .{ }^{34}$ However, Congress remained immune to these pleas throughout the National Banking era.

The third and last element of supervision, disciplinary action, was limited to moral suasion the revocation a bank's charter. Consequently, prudential supervision was circumscribed, with the Comptroller relying upon the cooperation of the directors and officers of a bank to correct violations. ${ }^{35}$ Although many Comptrollers emphasized the importance of discussing the principles of good management with bank officials and requesting correction of problems, the Office of the Comptroller did not accept responsibility for a bank's mistakes. Comptroller Knox wrote:

\footnotetext{
${ }^{31}$ Robertson, (1968), pp. 76-79.

${ }^{32}$ U.S. House of Representatives, (1894), p. 197.

${ }^{33}$ U.S. Comptroller of the Currency, (1901), p. XVIII.

34 "This is a matter of very great importance in the interest of good administration, and the effective supervision of national banks. Every Comptroller of the Currency has agreed in this opinion, and has recommended that this change be made. The examination and supervision of national banks will never be what it should be, until this recommendation is carried out.” U.S. Comptroller, (1906), p. 65.

${ }^{35}$ Robertson, (1968) p. 71, note 13.
} 
It is scarcely to be expected, if a robber or a forger is placed in control of all its assets; that a national bank can be saved from disaster by the occasional visits of an examiner. ${ }^{36}$

\section{The Operation of the Office of the Comptroller of the Currency}

Supervision by the OCC was thus intended to reinforce market discipline, primarily through disclosure requirements and surprise examinations, where assets were marked to market and prompt closure was enforced for insolvent institutions. A review of the extant records of the OCC reveals a remarkably light supervisory hand, as one might expect in such a regime.

Table 1 presents some basic numbers about national banks and the OCC from 1884, when the first budgetary data was reported, to $1913 .^{37}$ The second to fourth columns of Table 1 report the number of national banks and their nominal and real assets. $^{38}$ The more rapid growth after 1900 reflects effects of the Gold Standard Act of 1900, which lowered the minimum capital requirement, permitting entry of considerably smaller institutions. At the same time the size of large city institutions was expanding, so that even with the growth of small banks the average size of a bank was 20 percent larger in real terms after 1900 compared to the previous decade. Columns 5 and 6 show the total nominal and real assessments levied on the banks to cover the salaries and expenses of examiners. Unfortunately, the number of examiners in Column 7 is much rarer information; but taken with the data on revenues to pay their compensation, the pattern shows a very modestly-sized agency growing with its expanding industry.. In 1889, there were only 30 examiners for 3,239 national banks. The number of examiners grew, increasing from 75 in 1902 to 114 in 1908. Yet, this remained a small staff, as the number of national banks increased from 6,007 in 1902 to 8,710 in 1908.

\footnotetext{
${ }^{36}$ U.S. Comptroller of the Currency, (1881), pp. 38.

37 There may have been a very important private complement to the limited examinations under the OCC in this period. The 1907 U.S. Comptroller of the Currency's Annual Report mentions the examination by the clearing houses and their improving quality. See Cannon (1910), pp. 137-147.

38 The GDP deflator is used to measure the real values. Carter (2006), Series Ca13.
} 
Table 1

The Operation of the OCC

1884-1913

\begin{tabular}{|c|c|c|c|c|c|c|c|}
\hline Year & $\begin{array}{l}\text { Number } \\
\text { of } \\
\text { National } \\
\text { Banks }\end{array}$ & $\begin{array}{l}\text { Assets } \\
\text { (\$ } \\
\text { Millions) }\end{array}$ & $\begin{array}{c}\text { Real } \\
\text { Assets } \\
\text { (1914 \$ } \\
\text { Millions) }\end{array}$ & $\begin{array}{c}\text { Assessments } \\
\text { for } \\
\text { examinations } \\
\text { (Current \$) }\end{array}$ & $\begin{array}{c}\text { Real } \\
\text { Assessments } \\
(1914 \text { \$) }\end{array}$ & $\begin{array}{l}\text { Number of } \\
\text { Examiners }\end{array}$ & $\begin{array}{c}\text { Banks } \\
\text { per } \\
\text { Examiner }\end{array}$ \\
\hline 1 & 2 & 3 & 4 & 5 & 6 & 7 & 8 \\
\hline 1884 & 2,625 & 2,283 & 2,908 & 99,642 & 126,941 & & \\
\hline 1885 & 2,689 & 2,422 & 3,134 & 107,782 & 139,460 & & \\
\hline 1886 & 2,809 & 2,475 & 3,282 & 107,273 & 142,266 & & \\
\hline 1887 & 3,014 & 2,637 & 3,461 & 110,220 & 144,627 & & \\
\hline 1888 & 3,120 & 2,731 & 3,578 & 121,778 & 159,512 & & \\
\hline 1889 & 3,239 & 2,938 & 3,946 & 130,726 & 175,560 & 30 & 108 \\
\hline 1890 & 3,484 & 3,062 & 4,142 & 136,773 & 185,016 & & \\
\hline 1891 & 3,652 & 3,113 & 4,166 & 138,969 & 185,959 & & \\
\hline 1892 & 3,759 & 3,494 & 4,625 & 161,984 & 214,441 & & \\
\hline 1893 & 3,807 & 3,213 & 4,246 & 162,445 & 214,669 & & \\
\hline 1894 & 3,770 & 3,422 & 4,689 & 251,967 & 345,236 & & \\
\hline 1895 & 3,715 & 3,471 & 4,799 & 238,252 & 329,479 & & \\
\hline 1896 & 3,689 & 3,354 & 4,596 & 237,804 & 325,830 & & \\
\hline 1897 & 3,610 & 3,563 & 4,882 & 222,859 & 305,354 & & \\
\hline 1898 & 3,581 & 3,978 & 5,391 & 225,445 & 305,521 & & \\
\hline 1899 & 3,582 & 4,709 & 6,324 & 244,904 & 328,896 & & \\
\hline 1900 & 3,731 & 4,944 & 6,487 & 259,165 & 340,068 & & \\
\hline 1901 & 4,163 & 5,674 & 7,266 & 277,816 & 355,758 & & \\
\hline 1902 & 4,532 & 6,007 & 7,524 & 307,297 & 384,897 & 75 & 60 \\
\hline 1903 & 4,935 & 6,285 & 7,554 & 324,599 & 390,148 & 74 & 67 \\
\hline 1904 & 5,330 & 6,653 & 7,820 & 346,895 & 407,725 & 76 & 70 \\
\hline 1905 & 5,664 & 7,325 & 8,582 & 388,307 & 454,962 & 83 & 68 \\
\hline 1906 & 6,047 & 7,781 & 8,838 & 396,766 & 450,678 & 91 & 66 \\
\hline 1907 & 6,422 & 8,472 & 9,095 & 425,158 & 456,446 & 100 & 64 \\
\hline 1908 & 6,817 & 8,710 & 9,405 & 429,398 & 463,675 & 114 & 60 \\
\hline 1909 & 6,886 & 9,365 & 10,113 & 510,928 & 551,713 & & \\
\hline 1910 & 7,138 & 9,892 & 10,410 & 524,039 & 551,464 & & \\
\hline 1911 & 7,270 & 10,378 & 10,968 & 492,269 & 520,239 & $113^{*}$ & 64 \\
\hline 1912 & 7,366 & 10,857 & 11,035 & 526,170 & 534,795 & & \\
\hline 1913 & 7,467 & 11,032 & 11,137 & 556,210 & 561,493 & & \\
\hline
\end{tabular}

Source: U.S. Comptroller of the Currency, (1884-1913).

*Estimate based on the average salary of an examiner and total salaries.

Examiners had considerable independence in conducting their examinations and hiring and paying their assistants, though the number of these individuals was apparently 
never reported to the Comptroller. ${ }^{39}$ Nevertheless, given the fixed compensation it is unlikely that the number of these assistants grew relative to the number of examiners over time, and thus the number of examiners and assessments represent a reasonable proxy for the effort expended in examination. The independence of examiners seems to have left some Comptrollers uncomfortable, and there were frequent requests to Congress to amend the National Bank Act to gain control over the appointment of assistants, set fixed salaries for both examiners and assistants, and require them to post bonds while taking an oath of office. ${ }^{40}$ However, there was no response from Capital Hill.

Even though the number of banks per examiner fell from over 100 in 1889, it remains to modern eyes, surprisingly high. For the period 1902 to 1911, it varied between 60 and 70 examiners per bank. At two required visits a year, each examiner would have to be performing 120 to 140 examinations per year. Given the time needed for travel between banks in the rural part of the country and given the size and complexity of large city banks, these reports could not have been exhaustive. Furthermore, bank assets appear to have been growing faster than the number of examiners. They rose from $\$ 80$ million per examiner in 1902 to $\$ 91$ million in 1911, suggesting that visits to a bank required more and more work.

In spite of this work load, national bank examiners seem to have been relatively well compensated. The average compensation for an examiner for 1902-1911 was approximately $\$ 4,307$. Even if their expenses consumed up to half of this sum, their pay would appear to be good in comparison to the Deputy Comptroller who was paid a salary of $\$ 2,500$, the clerks in the OCC’s Washington D.C. office who received $\$ 900$ to $\$ 1800$ or perhaps even the Comptroller who earned $\$ 5,000 .{ }^{41}$ At the same time, the average cost of an examination remained relatively low for a bank, rising from about $\$ 40$ to $\$ 70$ per year during this fifty year period.

Relatively little was written about the actual work of national bank examiners, given the confidential nature of their activities. One very knowledgeable banker, James

\footnotetext{
${ }^{39}$ The U.S. Comptroller of the Currency's Annual Report (1889) provides a description of some aspects of examination and refers to "the examiner, assisted by competent assistants." p. 55.

${ }^{40}$ U.S. Comptroller of the Currency, (1889), pp. 57.

${ }^{41}$ U.S. Comptroller of the Currency, (1889), pp. 85-86.
} 
B. Forgan, President of the First National Bank of Chicago believed that examiners had good intelligence about the state of a bank:

A competent examiner-and there are many such now in the government employ-while he can not pass judgment on all the loans in a bank, can, after a careful examination, or series of examinations, form a wonderfully correct judgment as to the general character of its assets and as to whether its management is good or bad, conservative or reckless, honest or dishonest. $^{42}$

Yet, examiners were not always this well-received. The Comptroller reported that while "some bank officers look upon the work of the examiners as unnecessary and inquisitorial," the "benefits derived from the visits of a competent examiner are, as a rule, fully appreciated by the managers of the associations." ${ }^{43}$ The Comptroller found that this "friendly attitude" was more common among banks "possessing ample capital and transacting an extended business" where the managers would not be able to personally supervise all the details of the business. Therefore, an independent knowledgeable outside review was sometimes appreciated in these circumstances. Examinations, except when fraud or insolvency was discovered, remained advisory. Forgan summarized the value of an examination:

Examinations, as they are now conducted, have a most beneficial influence on bank management, especially by way of restraint. The correspondence carried on by the Comptroller, based on the examiners' reports, does an inestimable lot of good in the way of forcing bank officers to comply with the law and in compelling them to face and provide for known losses as they occur. Supervision by examination does not, however, carry with it control of management and can not, therefore, be held responsible for either errors of judgment or lapses of integrity. Examination is always an event after the act, having no control over a bank's initiative, which rests exclusively with the executive officers and directors, and depends entirely on their business ability, judgment, and honest of purpose. ${ }^{44}$

Well aware that the examination process gave him only an advisory role, the Comptroller appears to have become much more anxious after the Panic of 1907.

\footnotetext{
${ }^{42}$ Cannon (1910), p. 138.

${ }^{43}$ U.S. Comptroller, pp. 55-56

${ }^{44}$ Cannon (1910), p.138.
} 
Attempting to pressure bank directors to become more attentive to the problems of national banks, the Comptroller ordered examiners to ask directors a set of fixed questions. When Philadelphia's national bank examiner, Frank L. Norris confronted the directors of the Philadelphia National Bank in 1908, they were angry and resentful. Questions included "How many of the Directors know the conditions of the Bank in all its details?" How many know nothing at all about the condition of the Bank? "Have the Directors full knowledge of the habits and general standing of the Bank's employees?” The president of the bank answered them perfunctorily and protested the right of the Comptroller to interrogate its directors and officers. ${ }^{45}$

The Comptroller's frustration appears to have been increasing on the eve of the passage of the Federal Reserve Act, even though there was no apparent increase in the number of insolvencies or their costs. The 1912 Annual Report reported an effort by the Comptroller to more forcefully engage the directors of national banks in the process of examination. ${ }^{46}$ The Comptroller reported that for years the agency had been urging directors to create examining committees of their own to look into the affairs of their banks at stated intervals, in order to supplement the work of the national bank examiners. ${ }^{47}$ The Comptroller complained that directors did not understand the nature of examinations and were unfamiliar with "the proper methods of verifying many assets and liabilities of the bank." 48 To remedy the situation, the Comptroller send a circular to all national banks on July 9, 1912, directing them to ensure that the directors would be able to provide national bank examiners will the best possible assistance at the next examination. In spite of these efforts by the Comptroller, the system of supervision set up by the National Bank Act remained largely unchanged until the Federal Reserve Act.

\footnotetext{
${ }^{45}$ Wainwright, (1953), p. 165.

${ }^{46}$ The concern about the quality of management appears to have been shared the Clearing Houses. Before the Panic of 1907, only the Chicago Clearing House had appointed an examiner (in 1906) to examine its member banks on a regular basis. Afterwards, the clearing houses in Minneapolis-St. Paul, St. Louis, Los Angeles, Kansas City and Philadelphia employed an examiner. Cannon (1910), pp. 137-147.

${ }^{47}$ U.S. Comptroller, (1912), p., 854-85

${ }^{48}$ U.S. Comptroller, (1912), p. 84.
} 


\section{The Supervision of State Banks}

Like regulation, supervision of state-chartered banks was generally lighter than the supervision experienced by national banks. In some states, the creation of a state bank commission or state banking board only occurred after the Panic of 1907. In general, the federal system of supervision came to be regarded as best practice; and the slow drift to adopting rules similar to those for the Comptroller of the Currency sped up after 1907. While state banks were generally subject to weaker supervision than national banks, trust companies largely escaped state supervision until after 1907. In New York, for example, the superintendant of banking did not have the power to take possession of a failing trust company until 1907, although he had been given this power for state banks in $1892 .^{49}$

For most of the National Banking era, state banks were required to provide one or two reports per year on their condition to a designated state official on specified dates. Towards the end of the period, states revised their laws on disclosure and followed the OCC's practice of requiring reports on days that were not known in advance by banks. ${ }^{50}$ Yet, even in 1910, the number of required reports was generally fewer than the Comptroller's five. Only nine states required five annual reports, twenty-two required four, nine required two, four required three, and one required one report. In all cases, state law required that the reports be published in local newspapers. After the Panic of 1907, more states came to regard the Comptroller's rules as best practice and several began making "call reports" on the same days as the OCC. ${ }^{51}$

Regular examinations only began to become the norm for state banks in the latter years of the century. Before 1887, only New York, Indiana, Minnesota, California and Iowa required regular examinations, though five additional states could make examinations if they believed that a bank was in trouble. ${ }^{52}$ By 1910, 41 states and territories authorized regular examinations of state banks, though twenty only called for one annual examination. Some of these states only set up regular examinations after the Panic of 1907. For example, California had no state supervision by examination until

\footnotetext{
49 Barnett (1911), p. 174.

${ }^{50}$ Barnett, (1911), p. 145.

${ }^{51}$ Barnett, (1911), p. 146.

52 Barnett (1911), p. 149.
} 
1909, when responding to public concern and a plan by the clearing houses to institute their own examinations, the legislature empowered the state supervisor to conduct them. ${ }^{53}$ In almost all states, examiners were paid a fixed salary, in contrast to the fees for national bank examiners that so troubled the Comptrollers. Most of the funds to compensate state examiners came from fees assessed on the banks.

Like the Comptroller, state bank supervisors' powers over their chartered banks was circumscribed and generally limited to taking action only when a bank was determined to be insolvent. While the Comptroller gained no additional authority immediately after the Panic of 1907, state legislatures granted more powers and discretion to state bank supervisors. By 1920, fifteen states gave bank supervisors the authority to "direct the discontinuance of unsafe and unauthorized practices." panic New York special commission was blunt:

Under existing law, he (the superintendent of banks) may criticize objectionable practices when they come to his knowledge, and report continued delinquencies to the attorney-general. His criticism is hence in large measure academic and may be given scant consideration by delinquents.....Were he clothed with the powers to "direct the discontinuance of unsafe practices," no institution would dare continue the same after having been admonished by him. ${ }^{55}$

Interestingly, no ability to fine or otherwise discipline banks, short of closure, was considered. Even in this respect, state bank supervisors had less power than the Comptroller of the Currency. The Comptroller had the power to appoint a receiver for a national bank, but a state bank examiner had to apply to the courts to appoint receivers for state banks and trust companies. Only after the Panic of 1907 did some states begin to follow the national bank practice. ${ }^{56}$

The minimal data that is available for the state banking authorities suggests that the resources available for state supervisors were more modest than those at the disposal of the Comptroller. The OCC's 1911 Annual Report provided a brief survey of the state

\footnotetext{
53 Cannon (1910), p. 146.

${ }^{54}$ Barnett (1911), p. 162.

55 Barnett (1911), p. 163.

${ }^{56}$ Barnett (1911), pp. 167-168. The 1907 New York special commission found that New York court appointed receivers in 1907 were more costly than those appointed by the OCC, absorbing 13 percent compared to 8.9 for the Comptroller-appointed receivers for the period 1865-190s. Barnett (1911), p. 169.
} 
systems of examination. According to this report, there were a total 224 state bank examiners for all states, compared to the 113 national bank examiners. However there were far more state banks, numbering $17,913,{ }^{57}$ implying that there were 80 state banks per state bank examiner, significantly more than the 64 banks per national bank examiner. This higher workload was not accompanied by higher compensation. State bank examiners were paid an average of $\$ 2,300$ compared to the average national bank examiner income of $\$ 4,356 .{ }^{58}$ Overall, while national bank supervision may have exercised a light hand, state surveillance of state-chartered banks and trust companies was minimal in the third-quarter of the nineteenth century and then slowly began to move towards the OCC's model of supervision.

\section{Consequences and Costs of Supervision, 1864-1913}

\section{A. The Role of Double Liability}

To evaluate the effectiveness of supervision in the National Banking era, there is one additional important feature of bank regulation---double liability---that needs to be discussed but which has hitherto received relatively attention. ${ }^{59}$ Concerned about the incentives for shareholders, Congress imposed double liability on the shareholders of national banks in the National Banking Act. In discussion of the Act, Senator John Sherman emphasized that the purpose of the rule was not only to provide greater protection from loss in the event of a failure but also to provide the appropriate incentives to shareholders. He argued that in addition to giving security to creditors, double liability "tends to prevent the stockholders and directors of a bank from engaging in hazardous operations." 60

Under the national banks' double liability rule, if a bank failed, shareholders at the time of failure could be forced to pay an assessment up to the par value of the stock in order to compensate depositors and other creditors. This regulation provided a strong incentive to owners to check the risk-taking activities of bank management. If a bank

\footnotetext{
${ }^{57}$ Carter (2006) Series Cj159.

${ }^{58}$ It should be noted that it is unclear in the report if the state examiners had to pay for their expenses out of their compensation.

${ }^{59}$ Grossman $(2001,2007,2010)$ is the only exception. He provides a careful survey of liability rules but probably understates their effects as his analysis focuses on the differences in liability among the state systems, which had weaker enforcement than national banks.

${ }^{60}$ Macey and Miller (1992)
} 
were faring poorly, the directors of a bank had the statutory right to vote to voluntarily liquidate the bank while it was still solvent, enabling them to protect shareholders from assessments. Consequently, to understand the operation of bank supervision, one needs to look at both insolvencies and voluntary liquidations---a phenomenon that has been overlooked.

Like many other dimensions of bank regulation, the assignment of liability to shareholders of state banks evolved over the National Banking Era. In 1870, 12 states imposed single liability, 18 states double, and the remainder had no law or statutes that were ambiguous. $^{61}$ By 1900, only five states did not fix shareholder liability, while 11 states elected to impose single liability and 32 chose double liability. However, there was a notable difference between the states assignment of liability and the National Banking Act. While the Comptroller had the right to impose an assessment on shareholders to pay out depositors, creditors of failed state banks, in most states, had to pursue shareholders in court, making collection of funds more costly and difficult. Furthermore, this state liability was enforceable only after the assets of the bank have been exhausted. In contrast, a national bank receiver could impose an assessment and begin distribution to depositors before a bank was finally closed. ${ }^{62}$ Given this generally weaker liability regime for state banks, it would be expected that the constraints on risk-taking would be reduced and it would be less likely that a troubled banks would voluntarily liquidated before it became insolvent.

\section{B. Voluntary Liquidations and Failures}

A comparison of national bank and state bank voluntary liquidations would be very instructive, but unfortunately, there are is no data on state bank voluntary liquidations. Consequently, analysis must be limited to national banks. Figures 4 and 5 display the number of national bank voluntary liquidations and insolvencies and the percentage of these relative to the total number of national banks. For the National

\footnotetext{
${ }^{61}$ Grossman (2007).

62 Barnett (1911), pp. 78-85. Seven states did provide an additional guarantee for depositors after 1907 in the form of deposit insurance schemes for their state-chartered banks. However, these short-lived guarantee systems did not play a major role in protecting the banking system See White (1983) and Kumbhakar and Wheelock (1994). Grossman (2007) finds that states the seven states that adopted deposit insurance had double liability in effect or legislated it at the same time
} 
Banking era, over four times the number of banks, 2,373 were voluntarily liquidated compared to 501 that were closed as insolvent. The total capital of voluntarily liquidated banks was $\$ 432.8$ million and for insolvent banks it was $\$ 89.1$ million. ${ }^{63}$

To the twenty-first century eye, the surprising feature of these charts is the number of banks that were placed in voluntary liquidation compared to the number that were insolvent. It suggests that shareholders and directors were quite cautious. When directors voluntarily liquidated a bank they appear to have been successful in picking the right moment, as few of these banks were subsequently found to be insolvent. ${ }^{64}$ When a bank was past saving, it was quickly closed by the authorities, revealing a readiness to close an insolvent bank that stands in stark contrast to today when closed banks all show substantial losses. Occasionally, the Comptroller erred and suspended a bank that was later found to be technically solvent and some of these were re-opened.

Figure 4

The Number of National Bank Voluntary Liquidations and Insolvencies 1864-1913

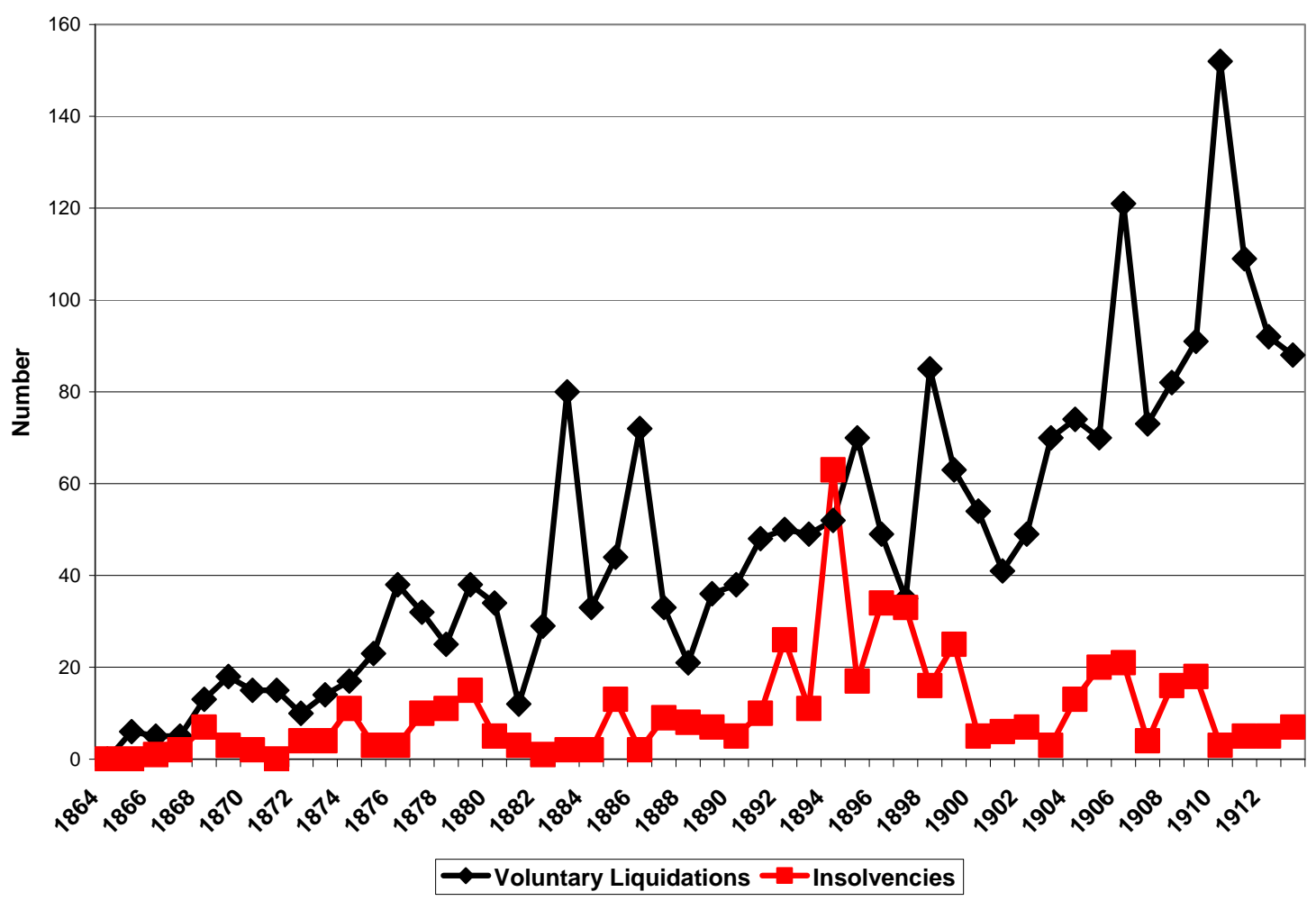

Source: U.S. Comptroller of the Currency (various years).

\footnotetext{
${ }^{63}$ U.S. Comptroller of the Currency, (1913), p. 104.

${ }^{64} \mathrm{~A}$ few of the liquidating banks were consolidated with other banks.
} 
Figures 4 and 5 also suggest that the worst years for national bank failures were the 1890s when the number and percentages of insolvencies peaked. By the first decade of the twentieth century, insolvencies have sunk to the low levels preceding the nineties, while voluntary liquidations are considerably higher. Whether it was the chastising experience of the 1890s or the increased vigilance of examiners, thanks to the growth in their number seen in Table 1, the national banking system appears to have more carefully protected the interested of its depositors.

Figure 5

The Percentage of National Bank Voluntary Liquidations and Insolvencies 1864-1913

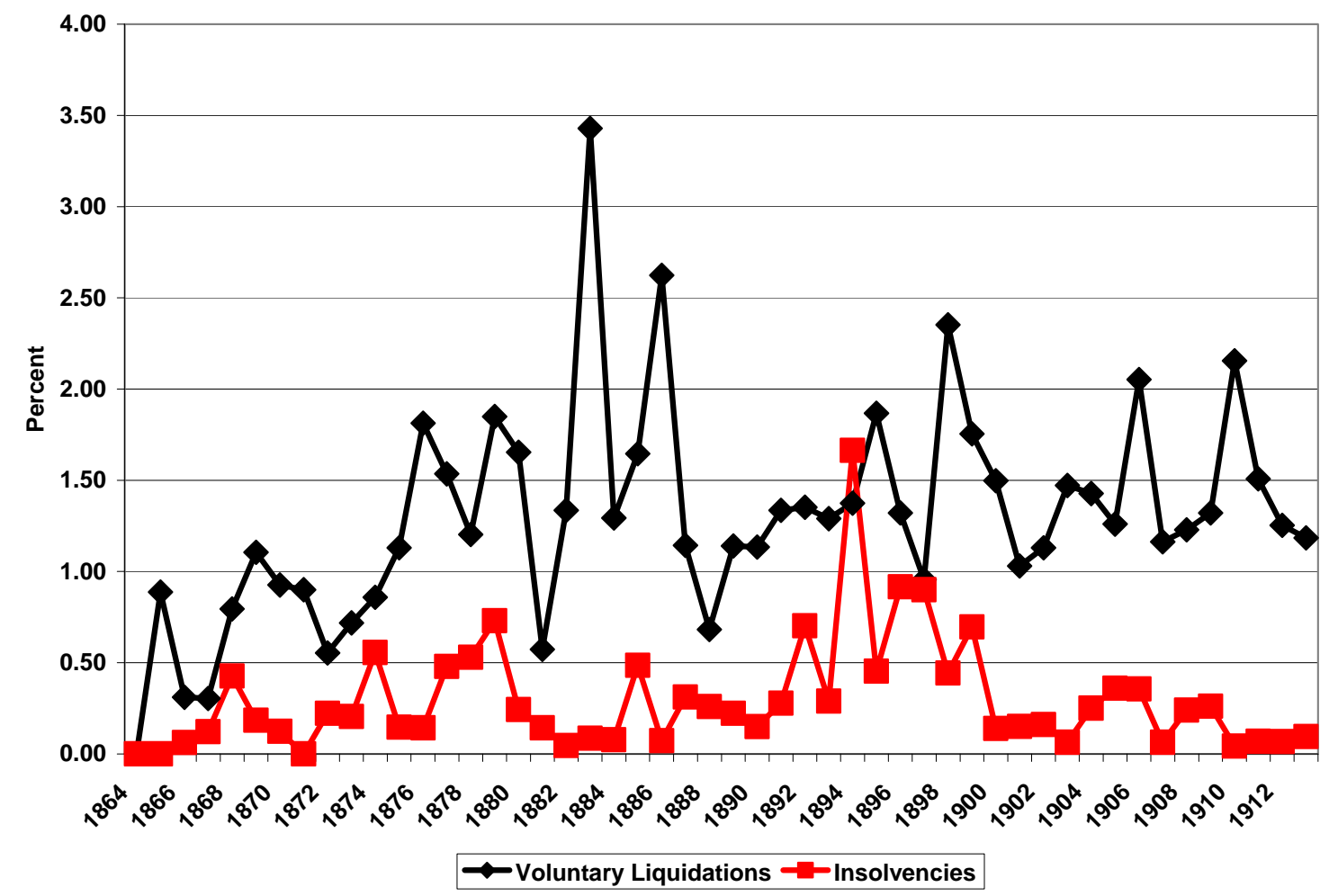

Source: U.S. Comptroller of the Currency (various years).

What losses were experienced by insolvent banks? Figures 6 and 7 show the number and percentage of national banks, state banks, and trust companies declared to be insolvent in each year between 1864 and 1913. Unfortunately, there is limited data for failures of state banks and trust companies before the 1890s; however failures of all types of institutions do appear to have been more frequent in the last decade of the nineteenth century than in the first decade of the twentieth, in spite of the severity of the Panic of 
1907. For the years where there is comparable data, the percentage of state banks failing was greater than the percentage of national banks and the percentage of trust companies failing higher than both. There is a notable spike in trust company failures in 1907, reflecting their fate during the Panic of 1907.

Figure 6

The Number of Bank Insolvencies

1864-1913

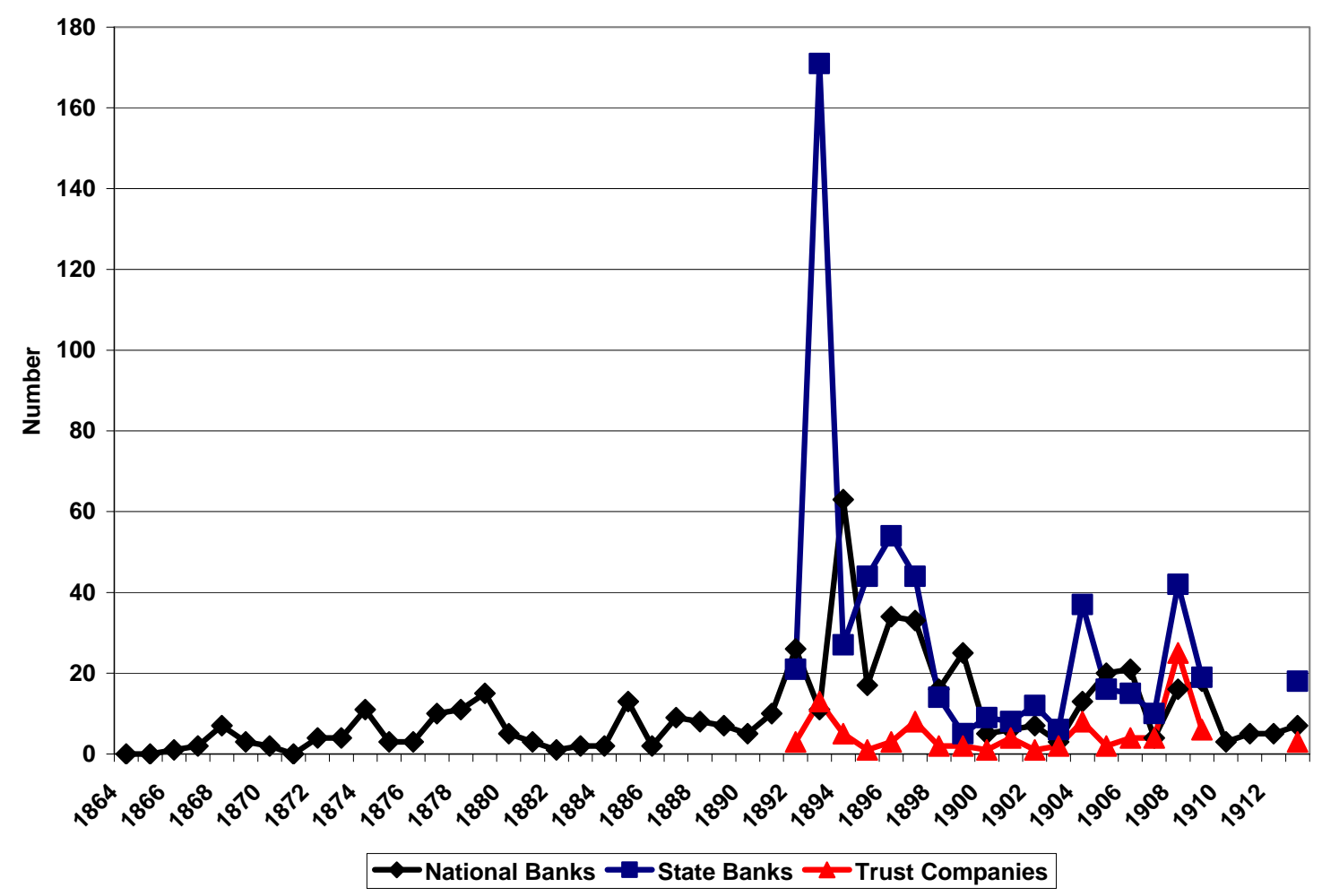

Sources: Barnett (1911), pp. 187, 190, 193, and 195; U.S. Comptroller of the Currency, (1913), p. 104.

These higher failure rates by state banks and especially trust companies suggest that they may have been taking greater risks. Because of the regulations that promoted smaller, less diversified state banks, they might be expected to have a higher failure rate and a higher loss rate. They might have protected themselves by increasing their capital relative to their assets to offset this danger. Figure 8 graphs the capital to asset ratio for state banks and national banks from 1834 until the creation of the Federal Reserve. This longer time frame provides a necessary perspective on the risk exposure of these institutions. Unfortunately, trust companies did not provide reports in most states that 
would enable an aggregate national capital to asset ratio to be measured for this group of intermediaries.

Figure 7

The Percentage of Bank Insolvencies

1864-1913

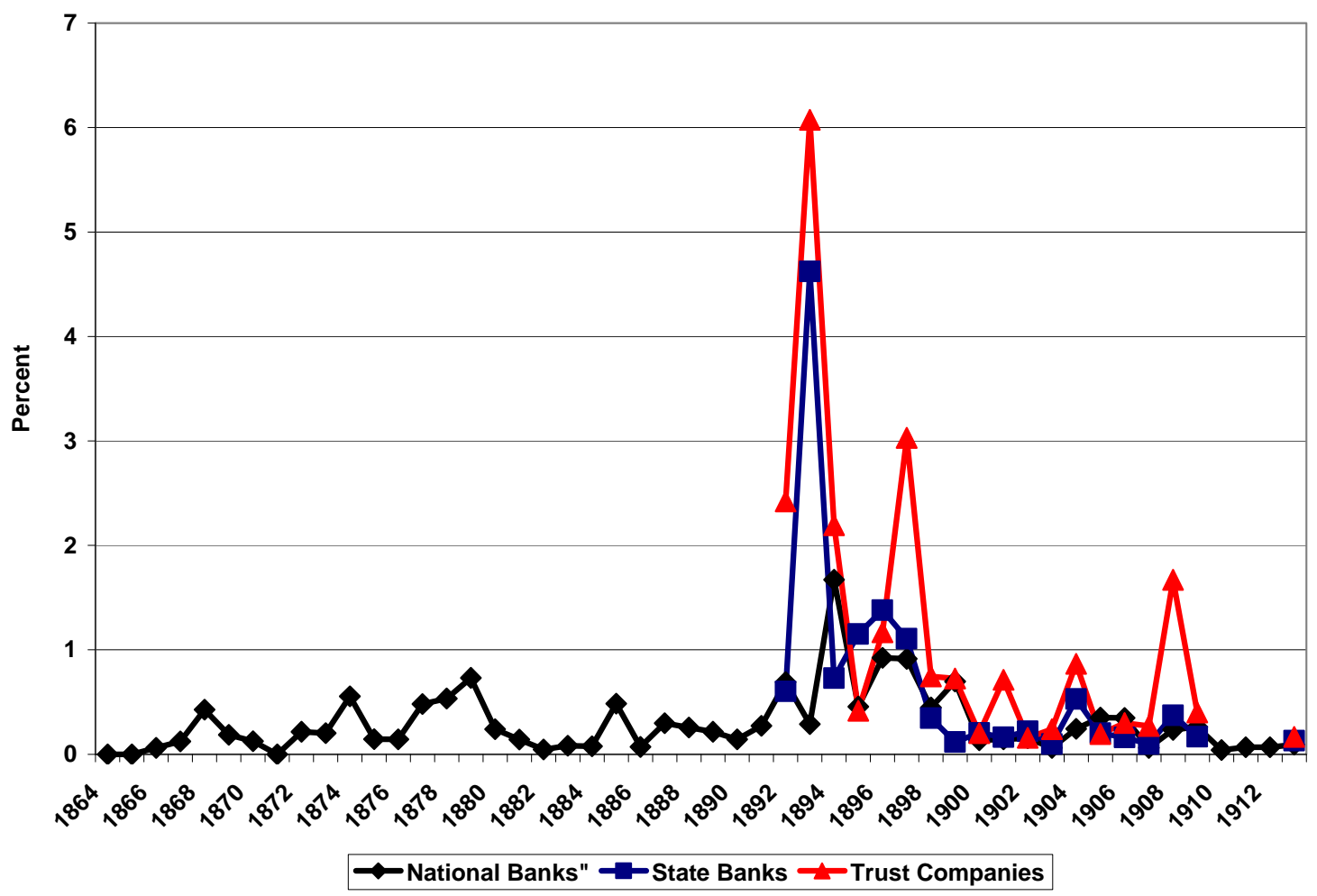

Sources: Barnett (1911), pp. 187, 190, 193, and 195; Comptroller of the Currency, (1913), p. 104. and Carter (2006).Series Cj203 and Cj212.

Figure 8 captures the well-known long downward trend of the capital to asset ratio over the course of the nineteenth century. ${ }^{65}$ This key ratio hovered around 40 percent for state banks in the late antebellum period, though it was higher in the 1840s. Visually, the national bank capital to asset ratio appears to continue the trend for preCivil War state banks, ultimately falling to around 20 percent. The surprise in Figure 8 is the much lower capital asset ratio for state banks in the late nineteenth century, suggesting that they were taking greater risks than national banks and perhaps higher returns. This assessment probably understates their risk-taking as their loan portfolios were not as constrained as national banks in most states, permitting them for example to lend extensively on real estate, enabling a greater maturity mismatch. If local banking

\footnotetext{
${ }^{65}$ Kaufman (1992).
} 
markets had been fully competitive, one would not expect to see the persistently lower capital to asset ratio and higher failure rates for state-chartered institutions. But, local banking markets, especially on the frontier had strong elements of local monopolies. The lower minimum capital requirements of state banks permitted the creation very small institutions in small towns where a national bank could not set up shop. ${ }^{66}$

Figure 8

\section{Capital to Asset Ratios for National Banks and State Banks} 1834-1929

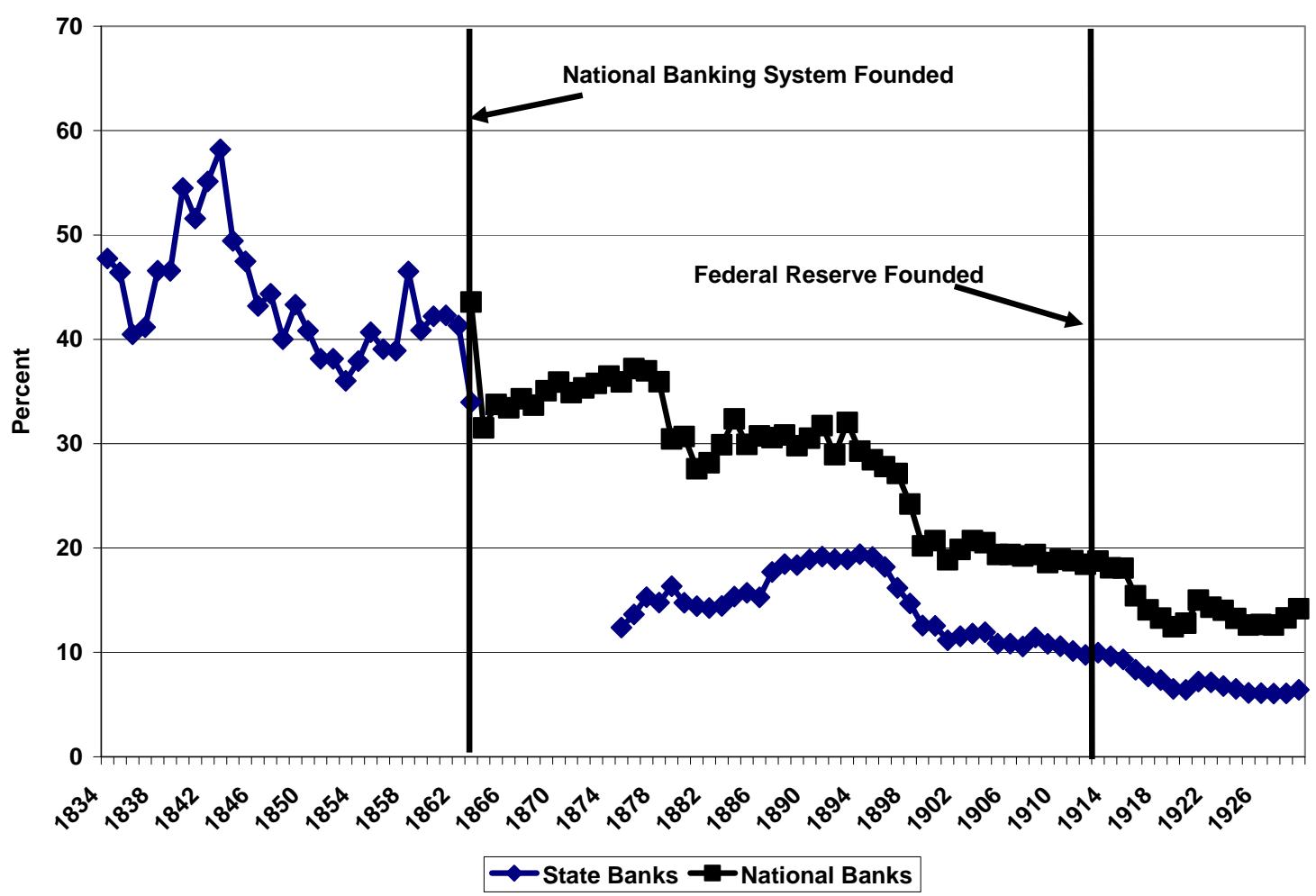

Source: Carter (2006) Series Cj150, Cj 157, Cj159, Cj175, Cj204, Cj211, Cj213, and Cj236.

\section{The Costs of Bank Failures}

The record of costs from the closure of national banks looks quite favorable relative to the experience of the Great Depression, the S\&Ls crisis, or the 2008 financial collapse. Between 1865 and 1913, 540 banks were declared to be insolvent. This number is higher than the 501 insolvencies that were compared to voluntary liquidations in Figures 5 because 39 were restored to solvency. These 540 national banks had an

\footnotetext{
${ }^{66}$ Bodenhorn (1995) and James (1978).
} 
initial capital of $\$ 86.8$ million or roughly on average $\$ 160,000$ each. The total assets of these banks on the date that were closed were $\$ 360$ million, of which 35.9 percent were estimated to be good, 31.5 percent to be doubtful, and 18.9 percent to be worthless with an additional 13.5 percent recovered since suspension. There were \$28.6 million of offsets for these banks. The receivers recouped $\$ 183.9$ million from the sales of assets and \$22.5 million in assessments on shareholders or 89.5 and 10.5 percent of the total collections. Tracking down and enforcing the assessments was clearly difficult and costly. Receivers assessed shareholders $\$ 46.4$ million but recovered only 48.6 percent of the total. The costs of closing these banks down were modest, with $\$ 5.4$ million spent on legal expenses and \$9.5 million spent on receivers' salaries or 4.1 percent of assets and 7.8 percent of the proven claims. Payments to depositors and other creditors totaled $\$ 146.9$ million out of $\$ 191.0$ million of proven claims for a payout ratio of 76.9 percent. Total losses thus amounted to $\$ 44$ million for this 50 year period.

Figure 9

National Bank Insolvencies and Payout Ratio 1865-1913

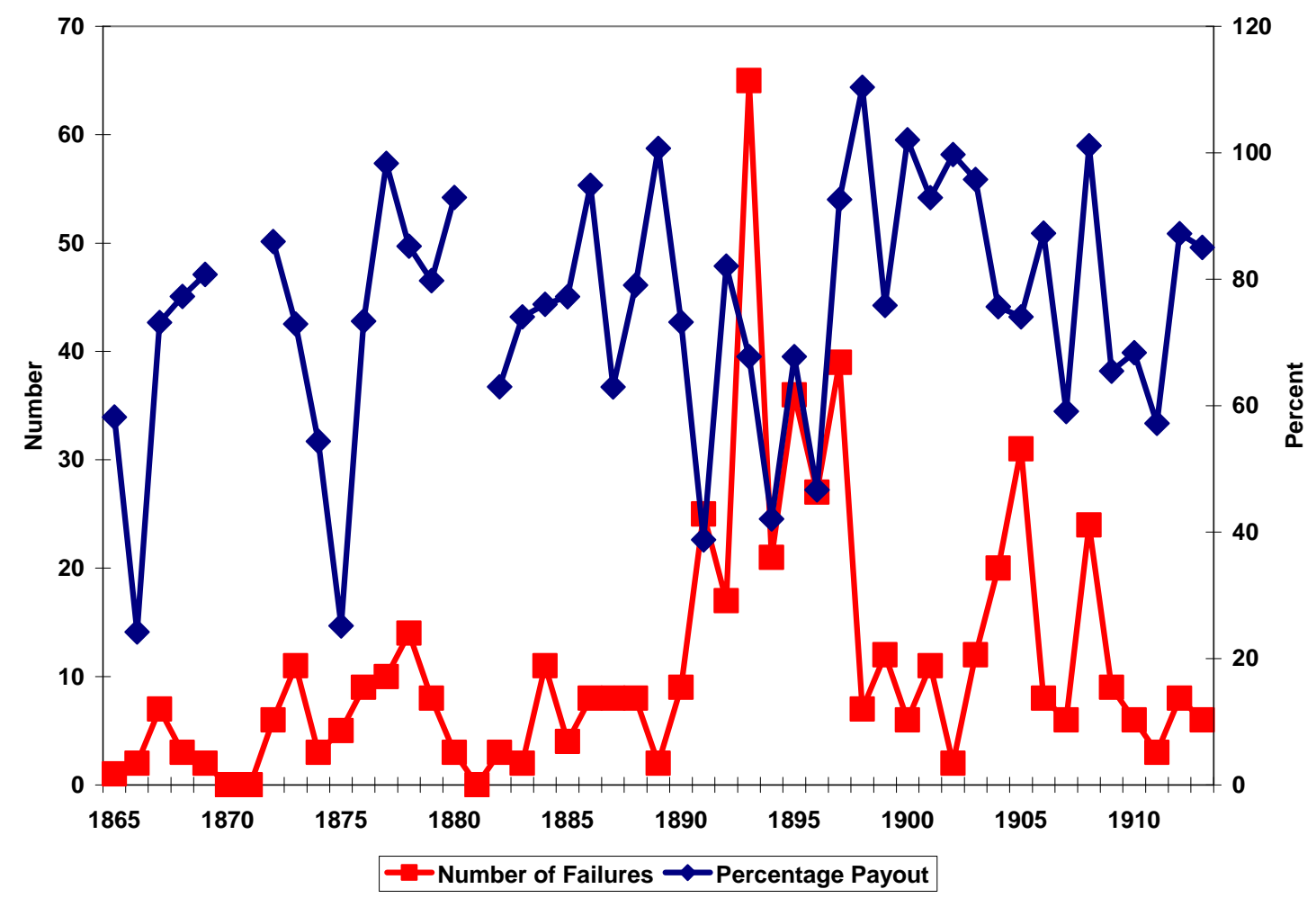

Source: U.S. Comptroller of the Currency, (1918).

Note: The payout ratio is calculated as the payments divided by the proven claims. If offsets are included, the recoveries by depositors would be higher. 
The sum of $\$ 44$ million represents a very modest cost, no matter how it is measured. In 2009 dollars, \$44 million is approximately \$1 billion, which would seem a relatively small sum for the cumulative losses. On average, losses were $\$ 880,000$ per year. This was a tiny fraction of the deposits of national banks, which even in 1870 stood at $\$ 706$ million in 1870 , growing to $\$ 1,085$ million in 1880 and $\$ 1,978$ million in $1890 .{ }^{67}$ In terms of GDP, \$880,000 and \$44 million were 0.01 and 0.6 percent of GDP in 1870 and 0.006 and 0.3 percent of GDP in 1890. These total losses are on the same order of magnitude as the losses that Hugh Rockoff calculated for the free banking era from 18381860, a nominal $\$ 1.9$ million or 0.01 percent of GDP. ${ }^{68}$ However, they pale next to the losses experienced during the Great Depression. Friedman and Schwartz calculated that \$2.5 billion were lost by depositors and shareholders during the years 1929-1933, representing 2.4 percent of contemporary GDP or \$39 billion in 2009 dollars. ${ }^{69}$ One estimate of the costs of the savings and loan and bank failures of the early 1980s was $\$ 126$ billion, or 3.4 percent of contemporary GDP and \$200 billion in 2009 dollars. $^{70}$ One estimate of the losses from the 2008-2009 collapse was \$1.7 trillion or 11.6 percent of 2008 GDP. ${ }^{71}$

One might argue that these aggregate numbers hid the pain of high losses in individual years, but that does not seem to be the case. Figure 9 reports the number of national bank failures in each year between 1865 and 1913 and the payout to depositors and other creditors. The decade of the 1890s, punctuated by panics and four recessions stands out as the worst experience, but national banks then returned to the previous pattern of failures and payouts. Yet, even in the most extreme years of 1891, 1894, and 1896 when payout ratio fell to 38.7, 42.1, and 46.7 percent, losses totaled \$4.2, \$2.2 and \$3.6 million. Given that national bank deposits stood at \$1,974, \$1,939, and \$2,141 million, losses were no more than 0.3 percent of all deposits.

Unfortunately, the record of losses from the state bank insolvencies has not been well preserved. As previously discussed, state bank supervisors were generally not given control over failed banks, and consequently few statistics on failures were collected by

\footnotetext{
${ }^{67}$ Carter (2006), Series Cj209.

${ }^{68}$ Rockoff (1975).

${ }^{69}$ Friedman and Schwartz (1963).pp. 351.

${ }^{70}$ White (1991).

${ }^{71}$ White (2009).
} 
these officials. Barnett's study for the National Monetary Commission (1911) only found four partial studies. Inference from these is difficult because no attempt was made to separate state, private and savings banks, partly because definitions of these institutions varied from state to state. In 1879, the Comptroller investigated the failures of state, private and savings banks for the three previous years and found that 210 banks failed, which had an average payout ratio of 66 percent. $^{72}$ Trust companies were omitted from this and subsequent studies. The Comptroller's own records show that there were 33 insolvent national banks from 1876 to 1878 , with payout ratios of $75.0,98.5$, and 91.3 percent for each year. ${ }^{73}$ In subsequent studies in 1895 and 1896, the Comptroller found that 1,234 of state and private institutions had failed since 1863 and had paid out less than 50 percent of claims. For national banks over the same span of years, 330 failed, paying out an average of 67.7 percent of proven claims. In 1899, the Comptroller examined state, private and savings banks that had failed between 1893 and 1899 and determined the payout ratio to be 56.19 percent. Over this same interval, national banks paid out 74.5 percent.

Barnett found one additional state study. In 1909, after reviewing the receivers' reports, the Secretary of the Nebraska State Banking Board compiled some statistics for 1901-1909. During this period, the average deposits of state banks totaled \$50 million.

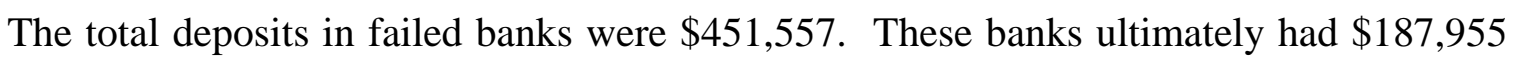
in unpaid claims, implying a recovery rate of 58 percent. $^{74}$ Assessing this information is difficult, though it would appear that the stricter liability rules and supervision of national banks led to better payout ratios. The only econometric study of the effects of double liability was conducted by Richard Grossman who found that double liability state banks were associated with lower risk taking and lower failures rates than single liability state banks. $^{75}$ However, his work only compares the effects of state regulations; the effects of stricter national bank rules, where the Comptroller not the courts enforced the laws, may have had a more profound effect on the safety of banks in the national system. Nevertheless, the state systems did not result in much larger losses to depositors. Even

\footnotetext{
${ }^{72}$ Unfortunately, these types of banks cannot be separately analyzed. Barnett (1911), p. 183.

${ }^{73}$ U.S. Comptroller of the Currency, (1920), Table 38, pp. 80-122.

${ }^{74}$ Cited in Barnett (1911), p. 182.

${ }^{75}$ Grossman (2001).
} 
though failures were more numerous, state banks were significantly smaller than national banks, so that total losses were probably around the same order of magnitude as those experienced by depositors of national banks. Addition of these losses to the totals for national banks would not alter the picture of very modest losses during the years 18631913 compared with subsequent crises.

\section{The National Banking System: An Assessment}

The National Banking era receives a mixed review in most historical accounts. While there was an expansion of banking services and an integration of money and capital markets, it is viewed as inherently flawed because of the large number of banking panics compared to the contemporary experience of other nations. ${ }^{76}$ However, it is important to understand the defects that contributed to these crises. First and foremost, the prohibition of branch banking created a system of thousands of unit banks, many of which had undiversified deposit bases and loan portfolios. To clear and collect checks and find better use for their seasonally fluctuating balances, the country and small city banks relied on their correspondents in large cities. Federal and state reserve requirements that permitted these banks to keep more than half their reserve on deposit in interest earning accounts with these same big city correspondent banks added further to these sizeable “bankers' balances. Investing heavily in the most liquid market of the day--call and time loans to the stock market---tied the fate of Main Street to Wall Street and visa versa. Many experts realized this key weakness of the system and its origin---the general prohibition on branching. But, calls for reducing the barriers to branching were met with fierce opposition from many unit banks that feared being driven out of business by branches of large banks. In spite of the weakness of individual banks, regulation and supervision set the incentives and level of monitoring that ensured that losses from bank failures were very, modest, if not minimal.

The second deficiency of the National Banking era was more widely acknowledged: the absence of a central bank. Contemporary experts and most historians believe that a lender of last resort could have squelched most panics by providing credit to liquidity-constrained banks in the midst of a crisis. The identification of this problem

\footnotetext{
${ }^{76}$ On the integration of financial markets, see Bodenhorn (1995).
} 
points to the key fact that these panics were liquidity rather than solvency events. Although a few insolvent institutions might provoke initial bank runs, there were no system-wide failures or losses. Which of these two problems was pre-eminent? Many countries like the United Kingdom, France and Germany had both central banks and widespread branching. But, the Canadian experience offers a useful comparison. With a similar distribution of economic activity and seasonally fluctuating demands for credit, Canada had an economic structure similar to that of the U.S. The critical difference was that Canada permitted nation-wide branching but had no central bank until $1935 .^{77}$ In contrast to the U.S., Canada did not suffer from frequent numerous bank runs and panics, pointing to a well-diversified integrated banking system as essential to limiting panics. This comparison suggests that the first priority of Congress should have been to reform the nation's banking structure. The political economy of banking, however, made this impossible and hence reformers focused on the establishment of the Federal Reserve.

\section{The Advent of the Fed}

\section{A. The Incomplete Reform of Regulation and Supervision}

While the primary focus of the Federal Reserve Act of 1913 was the creation of a central bank that would be palatable to the banks and the public, the legislation did attempt the needed restructuring of the banking system. The reforms of 1913 were not as bold as the reforms under taken in 1863-1864, leaving a good portion of the financial system under control of the states. During the Civil War, Congress was willing to take a stick to the financial system---a tax on state banknotes---to induce banks to join the national banking system; but the Act of 1913 and subsequent amendments offered mostly carrots to bring banks into the Federal Reserve System. The problem with the establishment of the Federal Reserve from the point of view of regulation and supervision is that it set a precedent for patching up some of the problems and failing to fundamentally reform the system. The inability to do more directly contributed to the next great financial crisis of 1929-1933.

By setting up a central bank, the Federal Reserve Act created the potential for a conflict between the objectives of price stability and financial stability. The failure of the

\footnotetext{
${ }^{77}$ Bordo and Redish (1987) and Bordo, Redish and Rockoff (1994).
} 
early leaders of the Fed to quickly recognize the implications of this conflict contributed to the waves of bank failures in the early 1920s and the Great Depression. In addition, by giving the Federal Reserve authority to supervise state member banks the Act did not make a decisive decision about whether supervision should be located inside or outside of the central bank. While before 1914, there had been one federal banking agency that squared off with the numerous state agencies, the Federal Reserve Act was the first step in the multiplication of federal regulatory agencies that have inherently conflicted interests. $^{78}$ Concerned about effectively exercising their mandates, state and federal agencies in the 1920s gradually weakened regulation and supervision to induce banks to change their charter or member status, permitting "regulatory arbitrage.” Compounding these problems was a gradual reduction in transparency because the Federal Reserve banks were not official government agencies like the OCC and were not similarly subject to Congressional oversight. The overall philosophy of bank supervision that aimed at reinforcing market discipline continued to inform the activities of the OCC, but the Fed's additional concerns about its discount operations slowly began to undermine it.

\section{B. Conflict between the Fed and the OCC: Examinations}

The Federal Reserve Act created two conflicts between the Federal Reserve Board and the OCC. First while membership in the Fed of existing national banks was mandatory, the Federal Reserve Board had the right to decide on the membership application of any state-chartered banks. By granting a national charter to a bank, the Comptroller could create a new member bank without the approval of the Fed. Secondly, the Federal Reserve Act did not contain any provision that required the Comptroller to provide the Board or a Federal Reserve Bank with copies of national bank examinations. ${ }^{79}$ In his memoire of the Fed's early years, The Formative Period of the Federal Reserve System (1925), Governor W.P.G. Harding reported that during his eight

\footnotetext{
${ }^{78}$ While the Federal Reserve Act was pending in Congress, there was discussion about whether to have the OCC moved from the jurisdiction of the Treasury to the Federal Reserve Board or to simply abolish the OCC and transfer its operations to the Board. Such suggestions were rejected and the Comptroller was made a member of the Reserve Bank Organization Committee and a member ex officio of the Federal Reserve Board. The Comptroller was granted a salary of $\$ 7,000$ for his membership on the Board in order to raise his total salary to that of other board members (Harding, 1925, p.6).

${ }^{79}$ Harding, 1925, pp.6-7.
} 
year tenure, the Comptroller granted charters for several new national banks against the recommendations of Federal Reserve banks and even granted national charters to state banks that had been refused membership, thus ensuring that they automatically acquired it without the consent of the Board. As the OCC was directed to examine national banks twice a year, the Board deemed it unnecessary to have regular examinations, assuming that the OCC would furnish the Federal Reserve banks with copies of its examiners' reports. However, the Comptroller only provided limited reports, reserving the right to decide what information the Fed would receive.

The Comptroller of the Currency in office at the time of the creation of the Fed, John Skelton Williams, fought to maintain the prerogatives of the OCC and had icy if not hostile relations with the Fed. When Williams' five-year term as Comptroller expired on February 2, 1919, President Wilson nominated him for another five year term, But, several Senators blocked his nomination and no action was taken when Congress adjourned on March 4, 1919. Under the law William could continue as Comptroller until his successor was appointed. When the Sixty-Sixth Congress convened, the Senate Committee on Banking and Currency led by a hostile chairman refused to make a favorable report and no action was taken, even though there appeared to be a majority of Senators who would have voted for his appointment. By the end of 1920, this appeared to be a permanent impasse and Williams decided to retire from office early in March 1921. During this time he became increasingly hostile to the Board. He attacked the amount of credit available to New York City member banks in contrast to those in the interior and argued for lowering interest rates. ${ }^{80}$

In these circumstances and given the escalating number of banks failures, it is surprising how little discussion in the literature there is about examination and supervision. W. Randolph Burgess mentions the supervisory activities of the Federal Reserve banks only twice in his authoritative book The Reserve Banks and the Money Market (1927). In his analysis of the lending activities of these banks, he emphasizes that both safety of rediscounts and advances are ensured by the quality of the collateral and the shortness of the credit. Losses to the Federal Reserve banks were thus "negligible." Member banks were required to file statements of the customers who presented paper to

${ }^{80}$ Harding, 1925, p. 201-202, 209. 
the banks in excess of $\$ 5,000$. To verify the quality of the collateral, the New York Fed maintained a file on 50,000 to 60,000 individuals and businesses. Examination gets short shrift: "They [the Federal Reserve Banks] maintain staffs of bank examiners who from time to time examine member banks and still more frequently collaborate with federal and state authorities in such examinations." ${ }^{\text {81 }}$

In Burgess' view a key function of examination was to provide information to the Federal Reserve bank officers in charge of lending to members to "prevent too constant or too large use of borrowing facilities.” In New York, this gave the Fed a list of banks whose condition was not satisfactory so that loans to them could be scrutinized. Those banks that made use of Fed credit for an unreasonably long period were then subjected to special inquiries to determine the "necessity for the borrowing." ${ }^{82}$ If borrowing was in excess of its capital and surplus, the bank was automatically placed on the list for inquiry. ${ }^{83}$ Burgess emphasized the importance of discretion in handling each of these cases. The example he gives is very telling because it is a very different from the Comptroller's view of the nature of supervision:

Take as an example the perplexing problem of lending to a bank in the farming area of the Middle West in recent years. The First National Bank of Crestland is loaded with doubtful farm paper, much of it representing sometime equities in real estate. They bring all their good paper to the Federal Reserve Bank to rediscount. Shall the Reserve Bank take it and lend them the money? If the Reserve Bank refuses, failure may follow. If it makes the loan, it assumes the responsibilities of continuing in operation a bank probably insolvent. If failure should then come the depositors might find much of the good assets rediscounted at the Reserve Bank and unavailable to pay depositors. The Reserve Bank must consider not only the safety of its loan, but the interests of the depositors. Can the bank be saved by a loan? If not, will the depositors be better off under an immediate liquidation, or a later liquidation, when the bank may have dissipated many of its best assets? These are some of the questions the Reserve Bank has to face. The answer depends on a careful scrutiny

\footnotetext{
${ }^{81}$ Burgess, 1927, p. 29.

${ }^{82}$ Burgess, (1927), p. 234-235.

${ }^{83}$ Under the national banking system banks were not permitted to borrow in excess of their capital, but Federal Reserve Act allowed them to do so.
} 
of each bank, in constant cooperation with state and national supervisory authorities. (Burgess, 1927, p. 236-7)

On this matter the Fed ran into a conflict with the OCC, especially under Williams, which believed that it should not disclose the information collected during examinations to the Fed, except where it might have direct bearing on its discount operations. What Burgess recognized was the discount window had created moral hazard for banks that borrowed. Following Walter Bagehot's Lombard Street, a nineteenth century European central bank might not have worried about the total condition of a borrowing bank, just whether it had good collateral. But, the Fed apparently assumed responsibility for the depositors and creditors of the bank.

This shift in the approach to supervision was abetted by the struggle between the Fed and the OCC for control of supervision. This contest arose because the Fed tried to appease state member banks who objected being subject to the same, more stringent regulations as national banks. Rather than coerce them to adhere to these regulations and risk their departure from the system, the Fed slowly weakened supervision for all national and state member banks. Just as state banks did not jump to become national banks after the National Bank Act of 1864, so too were few state-chartered banks convinced of the benefits of Fed membership that they willingly submitted to its generally more rigorous regulations. The Federal Reserve Act had tried to bring in most institutions into the fold by a variety of changes, lowering reserve requirements and differentiating between demand and time deposits and giving trust powers to national banks. ${ }^{84}$ But, few state banks responded; and by 1917, only 53 of the over 19,000 state banks had taken out membership. Amendments to the Act of 1913 made membership slightly more attractive to larger state institutions and membership rose to 513 in 1918 and 1,042 in 1919, cresting at 1,648 in 1922. While these state banks accounted for half of all state banks' assets, there were still 19,000 outside the regulatory purview of any federal agency. At the same time the number of national banks under the aegis of the Comptroller slowly rose from 7,518 in 1914 to a peak of 8,236 in 1923. Needless to say, the Federal Reserve was very sensitive to any slippage in the number of its members.

\footnotetext{
${ }^{84}$ White (1983), Chapter 3.
} 
The most visible example of the effects of competition between agencies followed from the transfer of authority to request call reports from the OCC to the Fed and the resultant decline in the number of call reports. The Federal Reserve Act gave the Board of Governors the power to demand reports and examine member banks, but initially the OCC carried out examination of state member banks in addition to national banks. When in 1915, Comptroller Williams asked for a sixth report and more detailed information, he provoked a flood of complaints. ${ }^{85}$. As a consequence of this uproar and the inequality between the requirements imposed on national and state member banks, the 1917 Amendment to the Federal Reserve Act ordered state member banks to make their reports of condition to their Federal Reserve bank, setting the minimum number of call reports at three---not the five required of national banks. Furthermore, the power to set call dates was transferred to the Board. In 1916, the surprise call year-end call reports were abandoned. ${ }^{86}$

This regime shift was not completed until after Williams left office in late 1921. But, once he had departed, disclosure began to weaken. In 1922, the number of reports fell back to five---the number that had been requested continuously since $1870 .{ }^{87}$ Then in 1923, it dropped to four and remained at that level for 1924 and 1925 . There is no comment in the Annual Reports of the Comptroller of the Currency or the Federal Reserve Board or in the Federal Reserve Bulletin; but in 1926, there were only three call reports---one for April 12, June 30, and December 3. In 1927, the Board called for four reports, a number it adhered to in subsequent years. What is missing for 1926 is the report that was traditionally called for in October, a shocking omission as this is the most fateful month of the year for financial crises. Why was it omitted? While the answer may lie somewhere in the archives of the Federal Reserve, there are two possible reasons. The Fed could have been under pressure from the national banks to reduce their reporting and put them on a par with state member banks. If so, this is an example of the "competition in laxity” between state and federal regulators that had led to a reduction of capital and reserve requirements in the late nineteenth and early twentieth centuries and continues to

\footnotetext{
${ }^{85}$ See Kirn (1945).

${ }^{86}$ The next time a surprise year-end call was issued was in 1962. See White (1992), p. 18.

${ }^{87}$ For the random distribution of the call dates from 1869 to 1913, see the U.S. Comptroller of the Currency, (1913), p. 215
} 
bedevil contemporary American regulators. ${ }^{88}$ Alternatively, the Fed may have been alarmed by the condition of some banks, given that real estate values had begun to decline in the third quarter of 1926. The decision to skip the October call might have been made to give banks time to raise capital or make other adjustments. If this were the case, it represented a significant shift towards discretionary supervision.

The record of bank examination reveals no such obvious deterioration and in fact, the Federal Reserve Act adopted some of the recommendations that pre-1913 Comptrollers had long requested. The payment of a fixed fee for each bank examined had caused the examinations to be less than a surprise as examiners movements became more predictable as they sought to minimized travel costs. The new Federal Reserve regime eliminated this incentive and put examiners on a salary and paid their expenses. In addition they were provided with paid assistants. ${ }^{89}$ The OCC also gained an increased ability to monitor its examiners, reorganizing its operations by Federal Reserve District and appointing a chief national bank examiner with responsibility for all examiners in the district. ${ }^{90}$ Although the Comptroller was initially responsible for examining state member banks, the 1917 Amendment transferred this power to the Federal Reserve banks who organized their own examination departments. ${ }^{91}$

\section{Examination in the Early Fed Years}

The resources available to the Comptroller under this new regime are shown in Table 2. The increase in resources devoted to examination is marked, but probably reflects the need to manage the growing number of insolvencies. In 1915, the number of examiners was little different, perhaps a bit lower than in 1913. But, beginning in 1916, there is a steady rise, peaking in 1923 at 234 examiners, nearly double the number before the foundation of the Fed. As the number of national banks changed little, the number of banks per examiner declined to the mid-thirties. This change suggests that examiners had more time to spend per bank; however it is unclear how much of this increase was associated with the higher number of bank failures in the early 1920s. There are two

\footnotetext{
${ }^{88}$ See White (1983).

${ }^{89}$ U.S. Comptroller of the Currency, (1919).

${ }^{90}$ Kirn (1945), pp. 164-168.

${ }^{91}$ State banks complained about bearing the cost of state examinations in addition to those of the Fed, though the Board could accept state examinations in lieu of additional federal ones (Kirn, 1945, p. 164).
} 
series representing the resources that are not completely compatible nor do they overlap. The first is the traditional revenue from the fees or assessments from examinations, and the second is the reported examination expenses, which would include salaries and travel expenses of the examiners. Nevertheless, they show the same pattern, doubling in real terms from the years around the founding of the Fed to the mid-1920s, but again the published record is silent whether this represents any change in supervision activity or the management of failing banks.

Table 2

The OCC and Bank Supervision 1914-1929

\begin{tabular}{|c|r|r|r|r|r|r|r|}
\hline Year & $\begin{array}{c}\text { Number } \\
\text { of } \\
\text { Banks }\end{array}$ & $\begin{array}{c}\text { Number of } \\
\text { Examiners }\end{array}$ & $\begin{array}{c}\text { Examiners } \\
\text { Per Bank }\end{array}$ & $\begin{array}{c}\text { Nominal } \\
\text { Assessments }\end{array}$ & $\begin{array}{c}\text { Real } \\
\text { Assessments } \\
\mathbf{1 9 1 4} \mathbf{\$}\end{array}$ & $\begin{array}{c}\text { Nominal } \\
\text { Examination } \\
\text { Expenses }\end{array}$ & $\begin{array}{c}\text { Real } \\
\text { Expenses } \\
\mathbf{1 9 1 4} \mathbf{\$}\end{array}$ \\
\hline $\mathbf{1 9 1 4}$ & 7,518 & & & 520,607 & 520,607 & & \\
\hline $\mathbf{1 9 1 5}$ & 7,597 & 103 & 74 & 536,300 & 519,540 & & \\
\hline $\mathbf{1 9 1 6}$ & 7,571 & 124 & 61 & 577,763 & 496,943 & & \\
\hline $\mathbf{1 9 1 7}$ & 7,599 & 131 & 58 & 849,816 & 592,561 & & \\
\hline $\mathbf{1 9 1 8}$ & 7,699 & 137 & 56 & 994,626 & 595,335 & & \\
\hline $\mathbf{1 9 1 9}$ & 7,779 & 149 & 52 & $1,050,977$ & 613,758 & $1,181,449$ & 689,951 \\
\hline $\mathbf{1 9 2 0}$ & 8,024 & 153 & 52 & $1,184,027$ & 607,110 & $1,363,870$ & 699,324 \\
\hline $\mathbf{1 9 2 1}$ & 8,169 & 195 & 42 & $1,769,395$ & $1,064,212$ & $7,808,273$ & $4,696,326$ \\
\hline $\mathbf{1 9 2 2}$ & 8,225 & 214 & 38 & $2,159,510$ & $1,374,402$ & $3,839,805$ & $2,443,811$ \\
\hline $\mathbf{1 9 2 3}$ & 8,184 & 234 & 35 & $2,145,392$ & $1,327,930$ & $2,145,391$ & $1,327,929$ \\
\hline $\mathbf{1 9 2 4}$ & 8,049 & 226 & 36 & $2,293,545$ & $1,437,571$ & $2,168,731$ & $1,359,339$ \\
\hline $\mathbf{1 9 2 5}$ & 8,054 & 221 & 36 & & & $2,091,059$ & $1,287,871$ \\
\hline $\mathbf{1 9 2 6}$ & 7,912 & 221 & 36 & & & $2,295,122$ & $1,407,725$ \\
\hline $\mathbf{1 9 2 7}$ & 7,765 & 227 & 34 & & & $2,291,408$ & $1,439,871$ \\
\hline $\mathbf{1 9 2 8}$ & 7,635 & 219 & 35 & & & $2,308,250$ & $1,439,512$ \\
\hline $\mathbf{1 9 2 9}$ & 7,408 & 204 & 36 & & & $2,409,858$ & $1,497,857$ \\
\hline
\end{tabular}

Source: U.S. Comptroller of the Currency, (1914-1929).

The Federal Reserve banks initially relied on the Comptroller's examiners and state supervisors examiners, only slowly creating their own examination staffs. The Federal Reserve Board created its own staff of examiners whose numbers are shown in Table 3. Conscious that state-chartered banks had no desire to be examined by two regulatory authorities, the Fed was given discretion to use the reports of state authorities. As a result, the relatively large number of banks per examiner does not imply that the Fed make less effort than the OCC to examine its banks. 
Table 3

State-Chartered Member Banks

and Federal Reserve Board Examiners

1915-1929

\begin{tabular}{|r|r|r|r|}
\hline & $\begin{array}{l}\text { Number of } \\
\text { State } \\
\text { Member } \\
\text { Banks }\end{array}$ & \multicolumn{1}{|l|}{$\begin{array}{l}\text { Number of } \\
\text { Examiners }\end{array}$} & $\begin{array}{l}\text { Banks per } \\
\text { Examiner }\end{array}$ \\
\hline 1915 & 17 & 6 & 3 \\
\hline 1916 & 34 & 5 & 7 \\
\hline 1917 & 53 & 11 & 5 \\
\hline 1918 & 513 & 14 & 37 \\
\hline 1919 & 1042 & 20 & 52 \\
\hline 1920 & 1374 & 18 & 76 \\
\hline 1921 & 1595 & 18 & 89 \\
\hline 1922 & 1648 & 22 & 75 \\
\hline 1923 & 1620 & 22 & 74 \\
\hline 1924 & 1570 & 21 & 75 \\
\hline 1925 & 1472 & 21 & 70 \\
\hline 1926 & 1403 & 18 & 78 \\
\hline 1927 & 1309 & 17 & 77 \\
\hline 1928 & 1244 & 17 & 73 \\
\hline 1929 & 1177 & 18 & 65 \\
\hline
\end{tabular}

Note: For 1918-1929, the number of examiners includes assistant examines.

Source: Board of Governors (1943), p. 22, Board of Governors of the Federal Reserve System, Annual Report (1914-1929).

\section{Price Stability v. Financial Stability}

\section{A. The Unexpected Deflation Shock}

Against this backdrop of interagency conflict, the conflict between the twin goals of price stability and financial stability quickly emerged. When inflation began to pick up speed in 1920, the Federal Reserve responded by quickly raising interest rates. ${ }^{92}$ This action, often deemed to be an excessive response, produced a sharp recession and a significant deflation. There was no historical precedent that would have prepared the financial sector for this action. During the Civil War, the price level had more than doubled but the deflation that permitted the U.S. join the gold standard at its prewar parity was gradual, lasting from 1866 to 1879 . After World War I when the price level

\footnotetext{
${ }^{92}$ Friedman and Schwartz (1963), pp. 231-239 and Meltzer (2003), pp. 109-119.
} 
nearly doubled between 1914 and 1920, it tumbled 22 percent between 1920 and $1922 .^{93}$ Banks that had been riding the wartime and postwar booms were hit hardest, with the small banks in agricultural areas suffering the most as commodity prices plummeted.

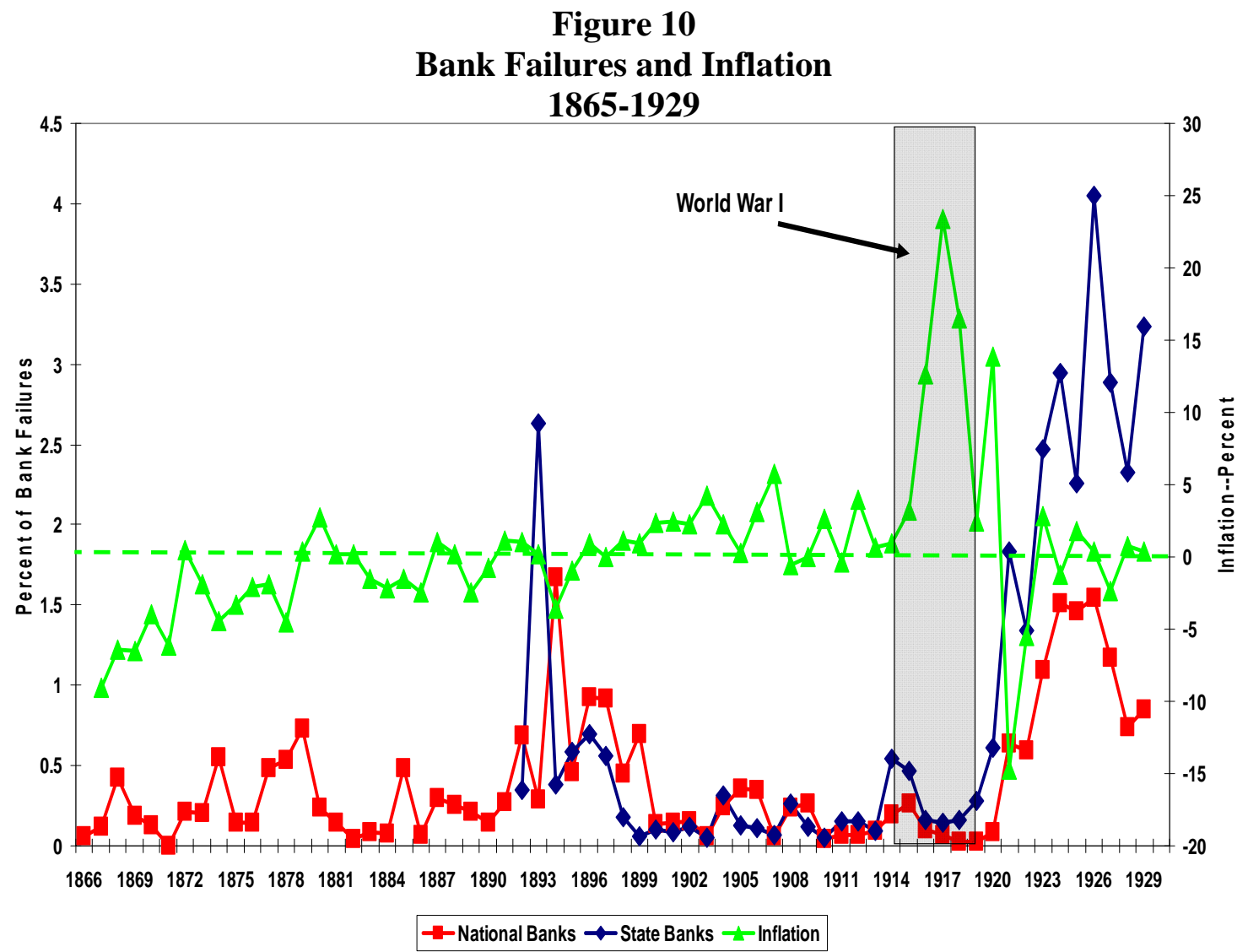

Sources: U.S. Comptroller of the Currency, (1914), p. 104; Board of Governors of the Federal Reserve System (1943), p. 283. Carter (2006), Series Ca13.

Figure 10 shows the percentage of state and national bank failures and the inflation rate between 1865 and 1929. The unprecedented deflation was accompanied by a lagged increase in bank failures, as its effects gradually brought a rise in farm foreclosures. ${ }^{94}$ During the years 1921-1929, 766 national banks and 4,645 state banks failed. The number of national bank insolvencies was far greater than the 501 insolvencies of 18651913. Worse yet, the payout ratio for national banks dropped to 40 percent for a total loss of $\$ 565$ million (\$6.9 billion in 2009 dollars) or $0.8 \%$ of 1925 GDP. ${ }^{95}$ The banking

\footnotetext{
${ }^{93}$ The price level is measured by the GDP deflator. Carter (2006), Series Ca13.

${ }^{94}$ Alston, Grove and Wheelock (1994).

${ }^{95}$ Calomiris and White (1994), pp. 170-172.
} 
system might have recovered from this one time shock, as it had recovered from the 1890s, with modest numbers of failures and relatively high payouts. However, the second great unanticipated deflationary shock of the Great Depression prevented a complete recovery. In addition, this onetime shock muddied the water for identifying other more subtle changes in policy described above.

\section{B. Seasonal Interest Rate and Discount Policies}

Beyond this deflationary event, two permanent features of the Federal Reserve changed the incentives for banks to take risks: its seasonal interest rate policy and its discount policy. In the Federal Reserve Act, the Fed was charged with furnishing "an elastic currency.” For the Fed it was a central obligation to eliminate the seasonal strain in financial markets. As its first Annual Report emphasized "its duty is not to await emergencies but by anticipation, to do what it can to prevent them."96 Miron (1986) documented that the Federal Reserve promptly carried out policies that reduced the seasonality of interest rates. Because panics occurred in periods when seasonal increases in loan demand and decreases in deposit demand strained the financial system, accommodating credit to seasonal shocks reduced the potential of a crisis. Comparing 1890-1908 and 1919-1928, Miron found the standard deviation of the seasonal for call loans fell from 130 to 46 basis points, with the amplitude dropping from 600 to 230 basis points. The reduction of seasonality in interest rates lowered the stress on the financial system, leading Miron to conclude that it had eliminated banking panics during the period 1915-1929. Most striking, was the absence of a panic during the severe recession of 1920-1921. Both the timing in the decline of seasonality and the role of the Fed have been challenged, but Miron's basic results have been upheld. ${ }^{97}$

This seasonal interest rate policy is visible in Figure 11, which displays the time rate for stock market loans and the commercial paper rate. Before the establishment of the Fed, businessmen and their bankers had to be wary of the sharp seasonal fluctuations, with the sometime accompanying financial panic. Once fears had been dampened, banks could more readily take risks, knowing that they would not be subject to the sharp interest

\footnotetext{
${ }^{96}$ Comptroller, Annual Report (1914), p. 17.

${ }^{97}$ See Clark (1986), Mankiw, Miron, Weil (1987), Barsky, Mankiw, Miron and Weil (1988), Fisher and Wohar (1990), Kool (1995), and Carporale and McKiernan(1998).
} 
rate spikes in the past. In this environment, a quick deflationary shock such as 19201921 or a longer one, such as 1929-1933, would take a heavier toll on exposed financial institutions.

\section{Figure 11 \\ Interest Rates \\ 1890-1934}

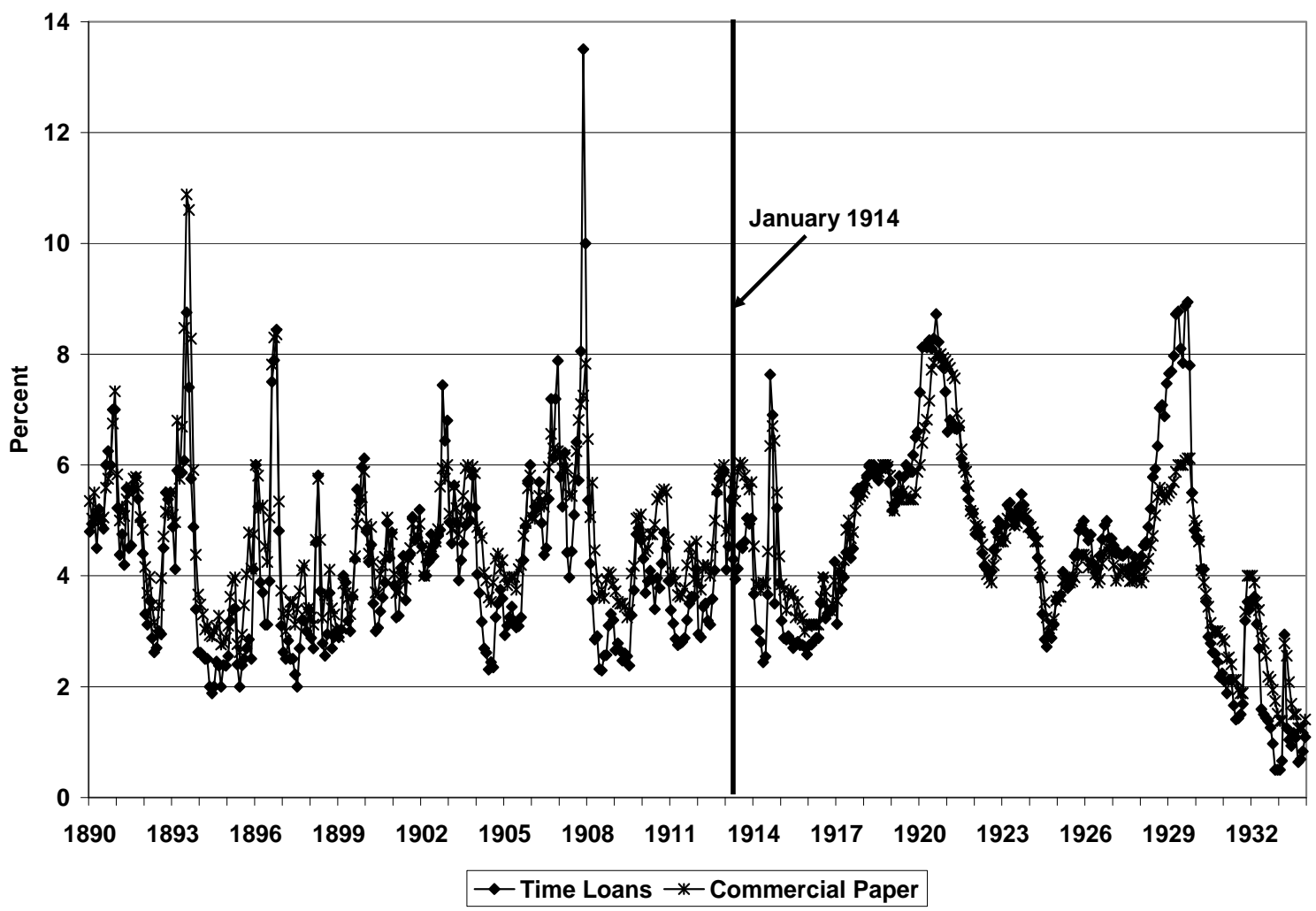

Source: Board of Governors of the Federal Reserve System (1943), pp.458-451.

In addition, a bank which found itself in trouble could, if it were a member of a

Federal Reserve bank, borrow at the discount window. Banks in trouble now had a new option. Where before they could voluntarily liquidate or continue with the risk of ultimately becoming insolvent. At the discount window, they could borrow using some of their good assets and try to recoup their losses. The danger for depositors and other creditors was that such a bank would pay out less if it failed because it had pledged more good assets at the Fed's window. This was the problem that Burgess had identified, though he thought that the "careful scrutiny" of the regulators would be sufficient to prevent this outcome. 
Unfortunately, contrary to Burgess's hopeful expectations, many banks became long-term borrowers at the discount window. In 1925, the Federal Reserve Board collected data on the indebtedness of member banks to their Federal Reserve banks. This information revealed that contrary to the expectations of the fathers of the Fed, the discount window turned out to have been more than a facility to increase short-term liquidity. On August 31, 1925, 593 banks had been borrowing for a year or more. ${ }^{98}$ Out of this total 239 had been borrowing continuously since 1920. These banks appear to have been severely troubled institutions and the Fed estimated that 80 percent of the 259 national member banks that had failed since 1920 had been "habitual borrowers." This problem was confirmed in later years. Of the 457 banks that had been borrowing for more than a year in 1926, 41 suspended operations in 1927 and 24 liquidated voluntarily or merged. ${ }^{99}$

\section{The Growing Cost of Bank Failures}

How did this regime affect the closing of banks and the losses to depositors and creditors? First, there was no change is the liability of national bank shareholders who were still subject to double liability. However, there was one significant change engineered by the Act of November 7, 1918. Before this act, if two national banks wanted to merge, one had to be liquidated to permit the other to purchase its assets and assume its liabilities. Out of the numerous voluntary liquidations, very few banks chose this option. After 1918, the two banks could consolidate under either charter, subject to approval of the Comptroller of the Currency. Previously prohibited from acquiring branches, this legal change gave national banks a crude means to acquire them in states where branching was permitted. ${ }^{100}$ While liquidations before 1918 had rarely been used as a means to consolidate, now banks that were weak might be tempted to combine with a stronger bank. This change in the menu of choices makes the comparison of bank closures before and after 1913 difficult.

\footnotetext{
${ }^{98}$ On June 30, 1925, there were 9,538 member banks. These 593 banks thus represented 6.2 percent of the total. Banking and Monetary Statistics (1943), pp. 22-23.

${ }^{99}$ Schwartz (1992), p. 58 and Burgess (1927), p. 236 who gives figures for 1923 and 1925.

${ }^{100}$ White (1985), p. 288.
} 
Table 4 provides data on national bank closures for the years 1921-1929. The number of annual suspensions, which approximates the number of insolvent banks, rose considerably during the twenties, largely because of the post-World War I agricultural crisis. Voluntary liquidations were less frequent and consolidations and absorptions were on the rise. Yet, even if one treats consolidations and absorptions as voluntary liquidations, as they might have been before 1914, then the sum of the two 113 and 1104 is still not twice the number of suspensions. In the National Banking era, voluntary liquidations outnumbered insolvencies by a factor of four. White knights may have been found for some troubled banks, but fewer banks were taking the cautious path of voluntary liquidation.

\section{Table 4}

Number of National Bank Closures

1921-1929

\begin{tabular}{|r|r|r|r|}
\hline Year & Suspensions & \multicolumn{1}{|c|}{$\begin{array}{c}\text { Voluntary } \\
\text { Liquidations }\end{array}$} & $\begin{array}{c}\text { Consolidations } \\
\text { and } \\
\text { Absorptions }\end{array}$ \\
\hline 1921 & 52 & 12 & 74 \\
\hline 1922 & 49 & 8 & 107 \\
\hline 1923 & 90 & 20 & 96 \\
\hline 1924 & 122 & 28 & 96 \\
\hline 1925 & 118 & 14 & 81 \\
\hline 1926 & 123 & 12 & 129 \\
\hline 1927 & 91 & 9 & 160 \\
\hline 1928 & 57 & 7 & 136 \\
\hline 1929 & 64 & 3 & 225 \\
\hline Total & 766 & 113 & 1104 \\
\hline
\end{tabular}

Source: Board of Governors of the Federal Reserve, Banking and Monetary Statistics (1943), p. 52.

Again the temporary deflationary shock of 1920-1921 makes it difficult to evaluate the change in the payout ratio for insolvent banks from the permanent innovations by the Fed. While this ratio averaged around 40 percent for the 1920s, the deflationary shock should have abated considerably by the end of the decade. However, the ratio only reached 50 percent in 1929, which is suggestive, though not conclusive 
evidence that banks were responding to the new incentives, taking increased risks relative to the years before $1913 .^{101}$

The changes in bank supervision witnessed in the first fifteen year of the Federal Reserve had subtle effects on bank behavior and outcomes. A small but significant minority of banks became dependent on the discount window, voluntary liquidations were down, suspensions increased, and payouts declined. These changes did not destabilize the system that had arisen during the National Banking era and aggregate losses remained very modest. In the absence of the Great Depression, Burgess'optimism might have eventually proved warranted if one is willing to make some strong assumptions. If competition in laxity and regulatory arbitrage had been brought under control and supervision reduced the number of borrowers at the discount window, bank failures and payouts might have returned to the lower levels of the pre-1913 era. If one doubts the ability to make these changes effective then the American banking system was stuck with a more costly supervisory regime.

\section{Après le Deluge}

These conjectures seem "academic" because of the change that swept over supervision with the Great Depression. The assumption of the New Dealers was that regime of regulation and supervision inherited from the National Banking System had failed. Yet this regime had kept losses to depositors to a minimum for the fifty years before 1914, in spite of a fragmented banking structure and the absence of a central bank. It even appears to have held up reasonably well after the creation of the Fed and the large unanticipated deflationary shock of 1920-1921. Nevertheless, because of a grand misdiagnosis, the New Deal swept aside this successful regime and imposed a radically different one that sharply increased moral hazard and risk-taking.

The depression devastated the banking system in the years 1929-1933. The unexpected series of deflationary shocks led prices to fall 23 percent and contributed to the 39 percent drop in GDP. ${ }^{102}$ In July 1929, commercial banks, which numbered 24,504, held $\$ 49$ billion in deposits. By the time the bank holiday ended only 11,878

\footnotetext{
${ }^{101}$ Calomiris and White (1994), p. 171.

102 Romer (1993), p. 22.
} 
banks with $\$ 23$ billion in deposits were deemed strong enough to open immediately. The losses from insolvent banks, half to depositors and half to shareholders, reached an unprecedented $\$ 2.5$ billion or 2.4 percent of GDP. ${ }^{103}$

As is well known, the defects of the banking system and even the character of bankers were held to be primary causes of the depression; and the New Deal responded with a major reform effort to alter regulation and supervision. Although the influence of specific lobbies within the banking industry, notably unit bankers and independent investment bankers have been identified in designing and lobbying for new regulation, the general argument was that the competitive market had failed and needed to be subjected to a thorough regulation. The competitive market was replaced by a loosely organized government cartel with controls on many dimensions of entry and pricing. This change was based on a failure to recognize that it was large deflationary shocks that had undermined the banking system and the rest of the economy, not unbridled competition.

The massive number of bank failures presented supervision with huge new challenges. In the past, it was thought that bank examiners could use market prices to judge the solvency of an institution. The increased volatility of price expectations, accompanying the jagged downward path of the economy, made the valuation of assets extremely difficult. But, instead of identifying the mistakes in monetary policy as the primary culprit, the reformers argued that markets failed to accurately value assets. Examiners were now instructed to value assets according to the "intrinsic value" they would have when the economy recovered. Supervision abandoned efforts to reinforce market discipline and instead was given discretion to make independent judgments, permitting forbearance in closing insolvent institutions that might recover later

The most high profile New Deal change, the creation of the Federal Deposit Insurance Corporation was accompanied by a change that has all but been forgotten---the abandonment of double liability. Shareholders under the threat of high assessments pleaded with legislatures to change the law, while the general public saw little benefit for retaining this rule. ${ }^{104}$ Additionally, it was assumed that since depositors were protected by

\footnotetext{
${ }^{103}$ Friedman and Schwartz (1963).pp. 351and the author’s calculation.

${ }^{104}$ Macey and Miller (1992).
} 
FDIC insurance, they would no longer need the protection afforded by double liability. The extra incentive for shareholders to more carefully monitor directors was erased, leaving supervision with a heavier monitoring burden. The visible effect of double liability, voluntary liquidations disappeared. Banks were not closed before they failed, or even shortly after they became insolvent. The increased difficulty of monitoring them and growing moral hazard, with perhaps forbearance, meant that they would be closed only when they were gravely insolvent.

The proliferation of New Deal and post-New deal federal regulatory agencies created more competition in laxity with opportunities for regulatory arbitrage and even regulatory capture. The sheer number of agencies involved in bank supervision, the OCC, the Fed, the FDIC, the SEC, the Federal Home Loan Bank Board, the Federal Home Loan banks, the Federal Savings and Loan Insurance Corporation, and the National Credit Union Administration made it more difficult for Congress to provide effective oversight.

The incentive effects of these vast changes were, however, hidden for decades. The Great Depression had winnowed out all but the stronger institutions and induced them to abandon loans for U.S. government bonds. To serve its enormous financing needs during World War II, the federal government pushed banks to enlarge even further their bond portfolios. ${ }^{105}$ By the end of the war, banks had become extremely safe institutions, and then it would take decades to unwind from their bond-saturated positions and permit the full effects of the New Deal incentives to operate. This adjustment was finished by the late 1970s, when inflationary shocks created a perfect storm that caused the New Deal regulatory system to collapse.

${ }^{105}$ Friedman and Schwartz (1963), Chapter 10. 


\section{References}

Alesina, Alberto and Andrea Stella, “The Politics of Monetary Policy,” National Bureau of Economic Research Working Paper, No.15856, (April 2010).

Alston, Lee J., Wayne A. Grove and David Wheelock, Why Do Banks Fail? Evidence from the 1920s," Explorations in Economic History 31:4 (October 1994), pp. 409-31.

Barnett, George E., State Banks and Trust Companies Since the Passage of the NationalBank Act (Washington D.C.: National Monetary Commission, Government Printing Office, 1911).

Barsky, Robert, N. Gregory Mankiw, Jeffrey Miron, and David Weil, “The Worldwide Change in the Behavior of Interest Rates and Prices in 1914," European Economic Review 32:5 (1988), pp. 1123-1154.

Bell, John Fred, "The Growth and Development of Banking Activities of Trust Companies,” Ph.D. dissertation, University of Illinois, Urbana, 1928).

Board of Governors of the Federal Reserve System, Annual Report (Washington D.C.: Board of Governors of the Federal Reserve System, 1914-1929).

Board of Governors of the Federal Reserve System, Banking and Monetary Statistics 1914-1941 (Washington D.C.: Board of Governors of the Federal Reserve System, 1943).

Bodenhorn, Howard, “A More Perfect Union: Regional Interest Rates in the United States, 1880-1960," in Michael D. Bordo and Richard Sylla, eds., Anglo-American Financial Systems (New York: Irwin, 1995), pp. 415-454.

Bordo, Michael D., and Angela Redish, "Why did the Bank of Canada Emerge in 1935?” Journal of Economic History 47:2 (June 1987), pp.405-417.

Bordo, Michael D., Angela Redish and Hugh Rockoff, “The U.S. Banking System from Northern Exposure” Journal of Economic History 54:2 (June 1994), pp. 325-341.

Burgess, W. Randolph, The Reserve Banks and the Money Market (New York: Harper \& Brothers, 1927).

Cagan, Phillip, and Anna Schartz, “The National Bank Note Puzzle Reinterpreted,” Journal of Money, Credit, and Banking 23:3, Part 1 (August 1991), pp. 293-307.

Calomiris, Charles W., and Eugene N. White, “The Origins of Deposit Insurance,”in Claudia Goldin and Gary D. Libecap, eds., The Regulated Economy: A Historical Approach to Political Economy (Chicago: Chicago University Press, 1994), pp. 145-188. 
Cannon, James Graham, Clearing Houses (Washington, D.C.: National Monetary Commission, Government Printing Office, 1910).

Caporale, Tony and Barbara McKiernan, "Interest Rate Uncertainly and the Founding of the Federal Reserve,” Journal of Economic History 58:4 (December 1998), pp. 11101117.

Carter, Susan B., Scott Sigmund Gartner, Michael R. Haines, Alan L. Olmstead, Richard Sutch, Gavin Wright, Historical Statistics of the United States Millenium Edition (Cambridge: Cambridge University Press, 2006).

Champ, Bruce, Neil Wallace, and Warren Weber, "Resolving the National Bank Note Paradox,” Federal Reserve Bank of Minneapolis Quarterly Review 16 (Spring 1992), pp. 13-21.

Clark, Truman, "Interest Rate Seasonals and the Federal Reserve," Journal of Political Economy 94:1 (February 1986), pp. 76-125.

Dunbar, Charles F., The Theory and History of Banking (New York: Knickerbocker, $5^{\text {th }}$ Revised Edition, 1929).

Economopoulos, A. J., “Illinois Free Banking Experience,” Journal of Money Credit and Banking 20:2 (1988), pp. 249-264.

Fisher, Raymond P.H. and Mark Wohar, "The Adjustment of Expectations to a Change in Regime: Comment,” American Economic Review 80:4 (September 1990), pp. 968-976.

Friedman, Milton and Anna J. Schwartz, A Monetary History of the United States, 18631960 (Princeton: Princeton University Press, 1963).

Grossman, Richard S., "The Macroeconomic Consequences of Bank Failures under the National Banking System,” Explorations in Economic History 30: 3 (July 1993), pp. 294320.

Grossman, Richard S., "Double Liability and Bank Risk Taking,” Journal of Money, Credit and Banking 33:2, Part I (May 2001), pp. 143-159.

Grossman, Richard S., "Fear and Greed: The evolution of double liability in American banking, 1865-1930, Explorations in Economic History 44:1 (January 2007), pp. 59-80.

Grossman, Richard S., Unsettled Account: The Evolution of Banking in the Industrialized World Since 1800 (Princeton: Princeton University Press, 2010).

Harding, W.P.G, The Formative Period of the Federal Reserve System (During the World Crisis (London: Constable and Company, Ltd., 1925). 
James, John A., "The Conundrum of the Low Issue of National Bank Notes,” Journal of Political Economy 84: 2 (April 1976), pp. 359-367.

James, John A., Money and Capital Markets in Postbellum American (Princeton: Princeton University Press, 1978).

Jalil, Andrew, "A New History of Banking Panics in the United States, 1825-1929: Construction and Implications," (University of California-Berkeley, November 1, 2009).

Kaufman, George G., "Bank Capital: Past, Present and Future," Journal of Financial Services Research, 5:4 (April 1992), pp. 385-402.

Kemmerer, Edwin W., Seasonal Variations in the Relative Demand for Money and Capital in the United States (Washington D. C.: National Monetary Commission, 1910).

Kirn, Brian A. Financial Reports of American Commercial Banks (Washington, D.C.: The Catholic University of American Press, 1945).

Kool, Clemens J.M., "War Finance and Interest Rate Targeting: Regime Changes in 1914-1918,” Explorations in Economic History 32:3 (July 1995), pp. 365-382.

Kumbhakar, Subal C. and David C. Wheelock, "The Slack Banker Dances: Deposit Insurance and Risk-Taking in the Banking Collapse of the 1920s," Explorations in Economic History 31:3 (July 1994), pp. 357-375.

Meltzer, Allan H., A History of the Federal Reserve Vol. 1 (Chicago: Chicago University Press, 2003).

Macey, Jonathan R., and Geoffrey P. Miller, "Double Liability of Bank Shareholders: History and Implications,” Wake Forest Law Review 27 (Spring 1992), pp. 31-62.

Mankiw, N. Gregory, Jeffrey A. Miron, David N. Weil, "The Adjustment of Expectations to a Change in Regime: A Study of the Founding of the Federal Reserve," American Economic Review 77:3 ( June 1987), pp. 358-374.

Miron, Jeffrey, "Financial Panics, the Seasonality of the Nominal Interest Rate, and the Founding of the Fed," American Economic Review 76:1 (March 1986), pp. 125-140.

Mishkin, Frederic S. "Prudential Supervision: Why Is It Important and What are the Issues? in Frederic S. Mishkin, ed., Prudential Supervision: What Works and What Doesn’t (Chicago, 2001), pp. 1-29.

Moen, Jon and Ellis W. Tallman, "The Panic of 1907: The Role of the Trust Companies,” Journal of Economic History 52:3 (September 1992), pp. 611-630.

Neal, Larry, “Trust Companies and Financial Innovation, 1897-1914,” Business History Review 45:1 (Spring 1971), pp. 35-51. 
Robertson, Ross, The Comptroller and Bank Supervision: A Historial Appraisal (Washington, D.C.: Office of the Comptroller of the Currency, 1968).

Rockoff, Hugh, “The Free Banking Era: A Reexamination,” Journal of Money Credit and Banking 6: 2 (May 1974), pp. 141-167.

Rockoff, Hugh, "Varieties of Banking and Regional Development in the United States, 1840-1860,” Journal of Economic History 35:1, (1975), pp.160-181.

Rolnick, Arthur J., and Warren E. Weber, "New Evidence on the Free Banking Era," American Economic Review 73:5 (December 1983), pp. 1080-1091.

Rolnick Arthur J. and Warren E. Weber, “The Causes of Free Bank Failures: A Detailed Examination,” Journal of Monetary Economics Vol. 14, No. 3 (November 1984), pp. 267-291.

Romer, Christina D., “Changes in Business Cycles: Evidence and Explanations,” Journal of Economic Perspectives 13: 2 (Spring 1990), pp. 23-44.

Romer, Christina D., “The Nation in Depression,” 7:2 Journal of Economic Perspectives (Spring 1993), pp. 19-39.

Schwartz, Anna J., “The Misuse of the Fed's Discount Window,” Federal Reserve Bank of St. Louis Review 74:5 (September/October 1992), pp. 58-69.

Sprague, Oliver M. W., History of Crises Under the National Banking System (Washington D. C.: National Monetary Commission, 1910).

U.S. Comptroller of the Currency, Annual Report (Washington, D.C.: U.S. Government Printing Office, 1864-1929).

U.S. House of Representatives, Hearings before the Committee on Banking and Currency $53^{\text {rd }}$ Cong. $1^{\text {st }}$ and $2^{\text {nd }}$ Sessions, 1893-1894 (Washington, D.C.: U.S. Government Printing Office, 1894).

Wainwright, Nicholas B., History of the Philadelphia National Bank: A Century and a Half of Philadelphia Banking, 1803-1953 (Philadelphia: Philadelphia National Bank, 1953).

White, Eugene N. The Regulation and Reform of the American Banking System, 19001929 (Princeton: Princeton University Press, 1983).

White, Eugene N., “The Merger Movement in Banking, 1919-1933,” Journal of Economic History Vol. 45, No., 2 (June 1985), pp. 285-291. 
White, Eugene N., The Comptroller and the Transformation of American Banking (Washington, D.C.: Office of the Comptroller of the Currency, 1992).

White, Eugene N., "Lessons from the History of Bank Examination and Supervision in the United States, 1863-2008," in Gigliobianco, A. and Toniolo, G., eds., Financial Market Regulation in the Wake of Financial Crises: The Historical Experience Banca d'Italia (2009).

White, Lawrence J., The S\&L Debacle: Public Policy Lessons for Bank and Thrift Regulation (Oxford University Press: New York, 1991).

White, Lawrence J., "The Role of Capital and Leverage in the Financial Markets Debacle of 2007-2008," Mercatus on Policy, 37, (February 2009). 